\title{
Detection of outflow of formaldehyde and glyoxal from the African continent to the Atlantic Ocean with a MAX-DOAS instrument
}

\author{
Lisa K. Behrens ${ }^{1}$, Andreas Hilboll ${ }^{1,2}$, Andreas Richter ${ }^{1}$, Enno Peters ${ }^{1, a}$, Leonardo M. A. Alvarado ${ }^{1}$, \\ Anna B. Kalisz Hedegaard ${ }^{3,1}$, Folkard Wittrock ${ }^{1}$, John P. Burrows ${ }^{1}$, and Mihalis Vrekoussis ${ }^{2,1,4}$ \\ ${ }^{1}$ Institute of Environmental Physics (IUP-UB), University of Bremen, Bremen, Germany \\ ${ }^{2}$ MARUM - Center for Marine Environmental Sciences, University of Bremen, Bremen, Germany \\ ${ }^{3}$ DLR - Institute of Atmospheric Physics, German Aerospace Center, Oberpfaffenhofen, Germany \\ ${ }^{4}$ Energy, Environment and Water Research Center (EEWRC), The Cyprus Institute, Nicosia, Cyprus \\ ${ }^{a}$ now at: DLR - Institute for protection of maritime infrastructures, German Aerospace Center, Bremerhaven, Germany
}

Correspondence: Lisa K. Behrens (lbehrens@iup.physik.uni-bremen.de)

Received: 10 December 2018 - Discussion started: 2 January 2019

Revised: 14 June 2019 - Accepted: 30 June 2019 - Published: 13 August 2019

\begin{abstract}
Trace gas maps retrieved from satellite measurements show enhanced levels of the atmospheric volatile organic compounds formaldehyde (HCHO) and glyoxal (CHOCHO) over the Atlantic Ocean. To validate the spatial distribution of this continental outflow, ship-based measurements were taken during the Continental Outflow of Pollutants towards the MArine tRoposphere (COPMAR) project. A Multi-AXis Differential Optical Absorption Spectrometer (MAX-DOAS) was operated aboard the research vessel (RV) Maria S. Merian during cruise MSM58/2. This cruise was conducted in October 2016 from Ponta Delgada (Azores) to Cape Town (South Africa), crossing between Cabo Verde and the African continent. The instrument was continuously scanning the horizon, looking towards the African continent. Enhanced levels of $\mathrm{HCHO}$ and $\mathrm{CHOCHO}$ were found in the area of expected outflow during this cruise. The observed spatial gradients of $\mathrm{HCHO}$ and $\mathrm{CHOCHO}$ along the cruise track agree with the spatial distributions from satellite measurements and the Model for OZone and Related chemical Tracers version 4 (MOZART-4) model simulations. The continental outflow from the African continent is observed in an elevated layer, higher than $1000 \mathrm{~m}$, and probably originates from biogenic emissions or biomass burning according to FLEXible PARTicle dispersion model (FLEXPART) emission sensitivities.
\end{abstract}

\section{Introduction}

\subsection{Trace gases exported to ocean areas}

Nitrogen oxides $\left(\mathrm{NO}_{\mathrm{x}}=\mathrm{NO}+\mathrm{NO}_{2}\right)$, formaldehyde (HCHO), and glyoxal (CHOCHO) are important air pollutants. Enhanced levels of these species can be observed over anthropogenically and naturally polluted areas, e.g. industrialised areas or biomass burning regions in Africa (van der A et al., 2008; De Smedt et al., 2008; Lerot et al., 2010; Alvarado et al., 2014). However, all three trace gases have also been observed over remote ocean areas, for example, over the equatorial Atlantic Ocean close to the African continent (e.g. HCHO: Wittrock et al., 2006; De Smedt et al., 2008; CHOCHO: Vrekoussis et al., 2009; Alvarado et al., 2014; Lerot et al., 2010; Wittrock et al., 2006; $\mathrm{NO}_{2}$ : Richter and Burrows, 2002; Boersma et al., 2008; van der A et al., 2008). These enhanced values measured over the ocean are low, often close to the detection limits of satellite instruments (Vrekoussis et al., 2009). Consequently, shipboard measurements of $\mathrm{HCHO}$ and $\mathrm{CHOCHO}$ are needed to validate the retrieved column amounts from nadir spacebased remote sensing instrumentation. Such validation is needed in support of the satellite measurements over remote ocean areas, and together with model simulations, they can improve our understanding of horizontal and vertical distributions of these gases.

Tropospheric $\mathrm{NO}_{2}$ is released to the atmosphere in large quantities from combustion, e.g. fossil fuels or biomass 

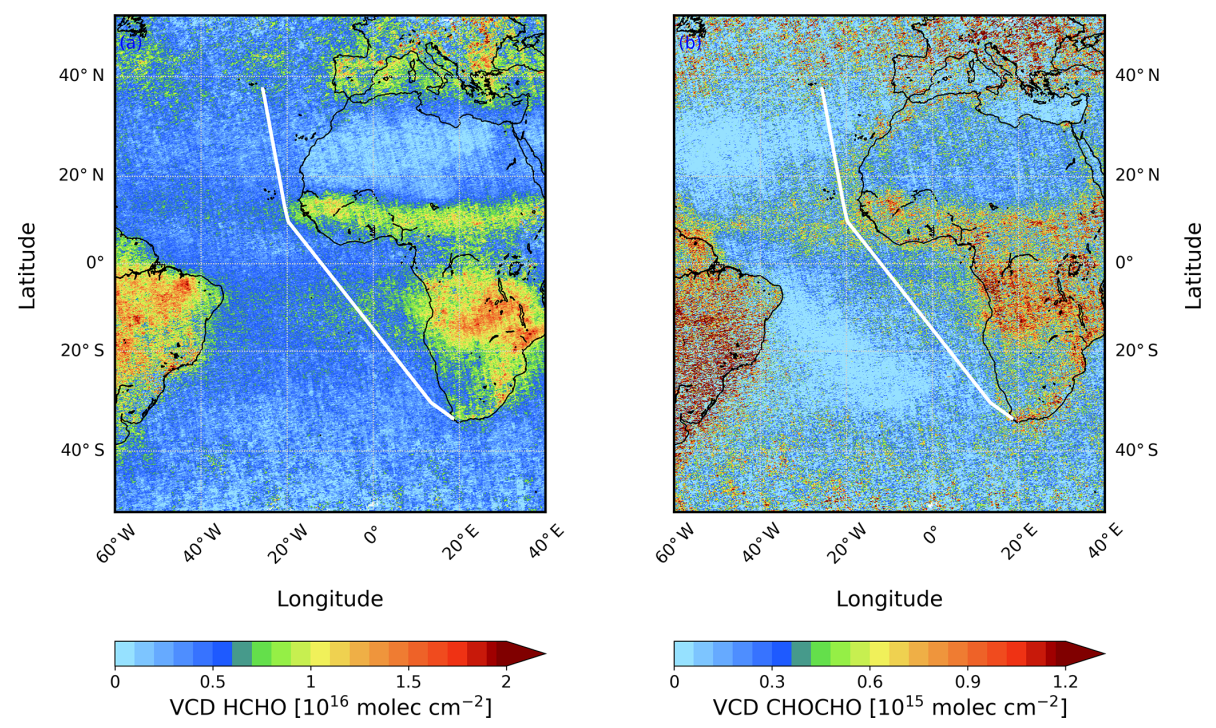

Figure 1. Monthly mean Ozone Monitoring Instrument (OMI) satellite data for (a) HCHO and (b) CHOCHO for October 2016. In white, the track of cruise MSM58/2 is shown.

(Lee et al., 1997). The importance of the individual $\mathrm{NO}_{2}$ sources varies by region (van der A et al., 2008). In Africa, for example, biomass burning is known to be an important seasonally varying source but anthropogenic sources are also of significance.

$\mathrm{HCHO}$ is the simplest and most abundant aldehyde in the atmosphere. The dominant sources are biogenic compounds such as isoprene which can be oxidised and form HCHO (Koppmann, 2007). Primary emissions are from biomass burning and the combustion of fossil fuels, but $\mathrm{HCHO}$ is also formed in the atmosphere from the oxidation of methane $\left(\mathrm{CH}_{4}\right)$ and non-methane hydrocarbons (Arlander et al., 1995). Due to the oxidation of $\mathrm{CH}_{4}, \mathrm{HCHO}$ is not only found close to its source regions, but a global background concentration of HCHO exists with surface levels of $0.2-$ 1.0 parts per billion (ppb) in remote marine environments (Weller et al., 2000; Burkert et al., 2001; Singh et al., 2001). Furthermore, it is an important indicator of the photochemical activity for a region (De Smedt et al., 2008; Vrekoussis et al., 2010). Generally, HCHO is a short-lived species $(\sim 5 \mathrm{~h})$. Therefore, enhanced HCHO values are usually found close to the emission sources, e.g. industrial areas and tropical rainforests (De Smedt et al., 2008), and suppressed levels over the remote ocean are expected as observed in satellite observations (Fig. 1a). However, Meyer-Arnek et al. (2005) showed that trace gases, including $\mathrm{HCHO}$, can be transported into the area above the southern Atlantic Ocean originating from biomass burning and from biogenic emissions.

$\mathrm{CHOCHO}$ is the smallest alpha-dicarbonyl compound in the atmosphere. It is an intermediate species formed by the oxidation of volatile organic compounds (VOCs) or by direct emissions from biomass burning and the combustion of fossil fuels (Stavrakou et al., 2009). The most important precursor for $\mathrm{CHOCHO}$ is biogenic isoprene with a contribution of nearly $50 \%$ globally (Fu et al., 2008). Similar to $\mathrm{HCHO}, \mathrm{CHOCHO}$ is a short-lived species with a lifetime of about $3 \mathrm{~h}$ on global average (Myriokefalitakis et al., 2008) which is removed by photolysis, by reactions with $\mathrm{OH}$ radicals, and by dry and wet deposition (Fu et al., 2008). Consequently, it is expected that CHOCHO is observed close to the formation regions, and "hotspot" areas of anthropogenic and biogenic emissions can be identified in global maps of CHOCHO columns derived from satellite measurements (Vrekoussis et al., 2010). Due to the short lifetime of $\mathrm{CHOCHO}$, no transport over long distances is expected, and therefore no CHOCHO should be observed over remote ocean areas. However, several studies of satellitederived $\mathrm{CHOCHO}$ columns reported enhanced $\mathrm{CHOCHO}$ levels over remote ocean regions (Fig. 1b): Lerot et al. (2010) proposed the transport of continental CHOCHO precursors to remote oceanic regions, whereas Vrekoussis et al. (2009) suggested that the observed amounts of $\mathrm{CHOCHO}$ are related to upwelling regions and thus oceanic emissions. These regions have a large concentration of phytoplankton with high biogenic activity which could contribute to the emission of CHOCHO. Also Sinreich et al. (2010) concluded that the ocean must be a source of $\mathrm{CHOCHO}$, because it was found up to $3000 \mathrm{~km}$ away from continental sources in the marine boundary layer. Stavrakou et al. (2009) included in their model a hypothetical additional biogenic source of $\mathrm{CHOCHO}$ over land. By including this additional source, they were able to improve the agreement between model and satellite observations over ocean which was related to an unknown $\mathrm{CHOCHO}$ precursor with a longer lifetime. Also Volkamer et al. (2015) considered an ocean source, although their results indicate another source of $\mathrm{CHOCHO}$. 


\subsection{Outflow of aerosols}

Outflow events from the African continent are regularly observed for aerosols, mainly between 0 and $20^{\circ} \mathrm{N}$ (Generoso et al., 2008). These aerosols originate from windblown desert dust (Fairlie et al., 2007) but also from biomass burning emissions and secondary organic aerosol from biogenic emissions (Chung and Seinfeld, 2002). The transported aerosols affect the atmosphere (e.g. visibility, radiation budget, and air quality) and ecosystems worldwide (Ridley et al., 2012). The dust emissions vary with time as they are influenced by different components of atmospheric circulation, e.g. Harmattan, Saharan heat low, and West African monsoon (Schepanski et al., 2017), and by surface conditions in the source regions, e.g. vegetation cover, and soil moisture (Ridley et al., 2012). If the dust aerosols are lifted, they can be transported westwards over long distances across the Atlantic. This transport is influenced by trade winds and shifts of the Intertropical Convergence Zone (ITCZ; Ridley et al., 2012; Schepanski et al., 2017). North of the Equator, the lowest aerosol optical depths (AODs) can be observed in northern hemispheric autumn (September, October, November: SON), when no biomass burning is present, and a peak in northern hemispheric summer (June, July, August; JJA; Ridley et al., 2012). Generally, the aerosol outflow is found in higher altitudes depending on the season: about $2000 \mathrm{~m}$ in winter (December, January, February; DJF) and about $5000 \mathrm{~m}$ in JJA (Ridley et al., 2012; Generoso et al., 2008)

Likewise, outflow events from Africa are regularly detected in the Southern Hemisphere. Anderson et al. (1996) observed outflow events of aerosols during a flight campaign in September/October 1992 where they found aerosols in the south Atlantic Ocean originating from Africa as well as from South America. The aerosols from the African continent were detected at an altitude between 3000 and $4000 \mathrm{~m}$.

\subsection{Structure of this paper}

This paper describes a study of $\mathrm{HCHO}$ and $\mathrm{CHOCHO}$ outflow from the African continent which was observed in Multi-AXis Differential Optical Absorption Spectrometer (MAX-DOAS) measurements collected during a ship cruise in October 2016. The paper is structured as follows. In Sect. 2, the Continental Outflow of Pollutants towards the MArine tRoposphere (COPMAR) project is described. In Sect. 3, the satellite and model data used for the analysis are introduced as well as the instrument used for the measurements. In Sect. 4, the measurement setup is evaluated using measurements of stratospheric $\mathrm{NO}_{2}$. Furthermore, the results for the individual species are presented, discussed, and compared with model data such as FLEXible PARTicle dispersion model (FLEXPART) simulations. Section 5 shows comparisons with previous studies. The paper ends with a summary and conclusions in Sect. 6.

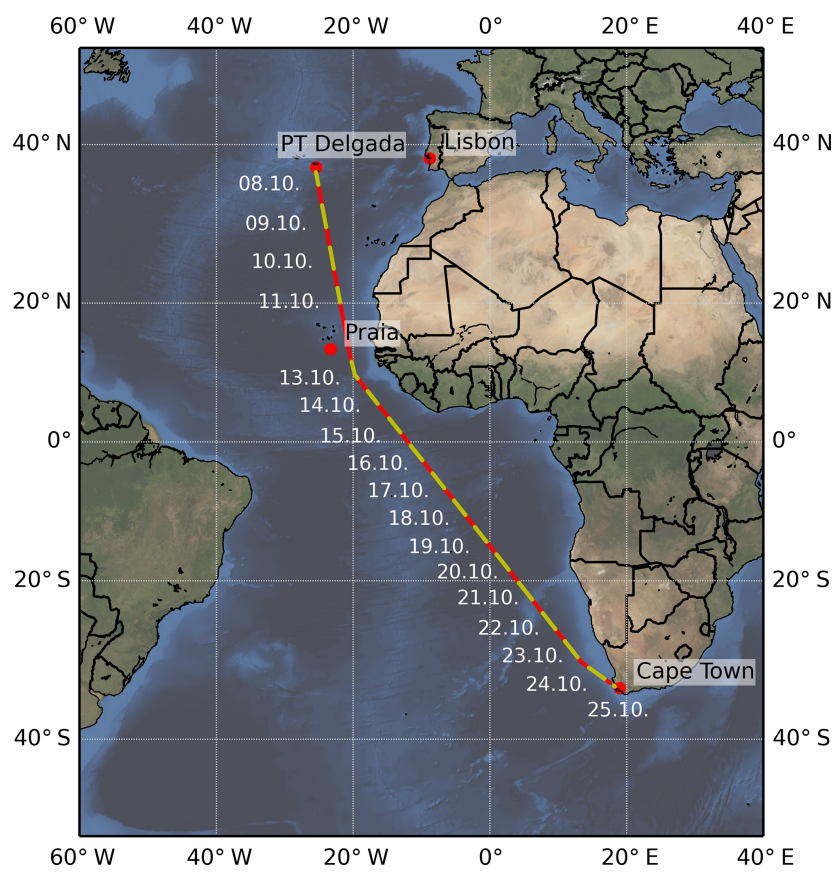

Figure 2. Cruise track (red) of MSM58/2 from Ponta Delgada (Azores) to Cape Town (South Africa). Times when the instrument was measuring are marked in yellow. On 12 October 2016, no measurements could be taken.

\section{The ship cruise - COPMAR project}

The COPMAR project took place aboard the German research vessel (RV) Maria S. Merian as part of cruise MSM58/2, which started in Ponta Delgada (Azores) on 8 October 2016, passed between Cabo Verde and the African Continent, and ended on 25 October 2016 in Cape Town (South Africa; see Fig. 2, Behrens, 2016). The aim of the COPMAR project was to measure the outflow of $\mathrm{HCHO}$ and $\mathrm{CHOCHO}$ from the African Continent in order to validate both satellite measurements and model simulations using MAX-DOAS, which was installed aboard the research vessel with the telescope unit oriented perpendicularly to the heading, pointing towards the African continent.

The weather and viewing conditions during the cruise are summarised in Table 1. On all days of the cruise, clouds were observed with varying cloud fractions, heights, and layers. However, only on $5 \mathrm{~d}$ were rain and poor viewing conditions observed $(14,15,18,19$, and 24 October 2016).

\section{Observations, modelling, and data analysis}

\subsection{MAX-DOAS measurements and instrument setup on the vessel}

The MAX-DOAS instrument used in this study consisted of an Avantes spectrometer (AvaSpec-ULS2048x64) with a wavelength range from 288 to $500 \mathrm{~nm}$, a spectral resolution 
Table 1. Weather and viewing conditions during COPMAR.

\begin{aligned} & \hline Time period Weather conditions \\ & \hline $8-9$ Oct 2016 mostly cloudy \\ & 10 Oct 2016 decreasing cloud fraction \\ & 11 Oct 2016 increasing cloud fraction \\ & 12 Oct 2016 no measurements \\ & 13 Oct 2016 partly cloudy, different layers \\ & 14 Oct 2016 mostly cloudy, afternoon: cloudy, rain \\ & 15 Oct 2016 cloudy, rain \\ & $16-17$ Oct 2016 increasingly cumulus clouds \\ & $18-19$ Oct 2016 mostly cloudy, rain \\ & 20 Oct 2016 mostly cloudy, different layers \\ & $21-22$ Oct 2016 morning: cloudy; afternoon: decreasing cloud fraction; evening: increasing cloud fraction \\ & 23 Oct 2016 partly cloudy \\ & 24 Oct 2016 morning: cloudy, rain, decreasing cloud fraction (mostly high clouds) \\ & 25 Oct 2016 nearly cloud-free \\ & \hline\end{aligned}

of $0.6 \mathrm{~nm}$ full width at half maximum (FWHM), and a telescope unit which was installed aboard RV Maria S. Merian. The instrument was continuously scanning a vertical plane pointing portside perpendicular to the vessel's direction, in order to generally point towards the African continent. Each scan lasted about $10 \mathrm{~min}$. In the vertical plane, elevation angles from -3 to $8^{\circ}$ were measured in $1^{\circ}$ steps as well as $10,15,30$, and $90^{\circ}$. A maximum exposure time of $0.1 \mathrm{~s}$ was used in order to be able to account for the ship's movement (roll angle) during data analysis. After correcting the angles for the roll of the ship, the individual measurements within a $30 \mathrm{~s}$ period were sorted by viewing angle and binned into $1^{\circ}$ intervals. Zenith sky measurements were averaged over $60 \mathrm{~s}$. For the analysis, elevation angles from 0 to $90^{\circ}$ above the horizon were used. Observations were taken at solar zenith angles (SZAs) smaller than $96^{\circ}$ for zenith sky measurements and for the off-axis at SZAs smaller than $90^{\circ}$.

The ship sailed at nearly constant speed over ground with $\sim 12-14 \mathrm{kn}$. The absolute wind direction was primarily from the south. Consequently, headwinds were dominant during the campaign, shifting either side of the bow (Fig. 3). Measurements with a relative wind direction between 90 and $270^{\circ}$ (grey-shaded wind directions; Fig. 3) are excluded from the analysis, because of possible contamination by the vessel's plume. Furthermore, an intensity filter was used to exclude poor viewing conditions during heavy rain events (i.e. very dark scenes) to avoid the entailed high uncertainties.

\subsection{Satellite measurements}

The measurement data obtained during the COPMAR project are compared with satellite measurements of absorber vertical column densities (VCDs) from the Ozone Monitoring Instrument (OMI; Levelt et al., 2006) and Global Ozone Monitoring Experiment 2A/B (GOME-2A/B; Callies et al., 2000; Munro et al., 2016) instruments.
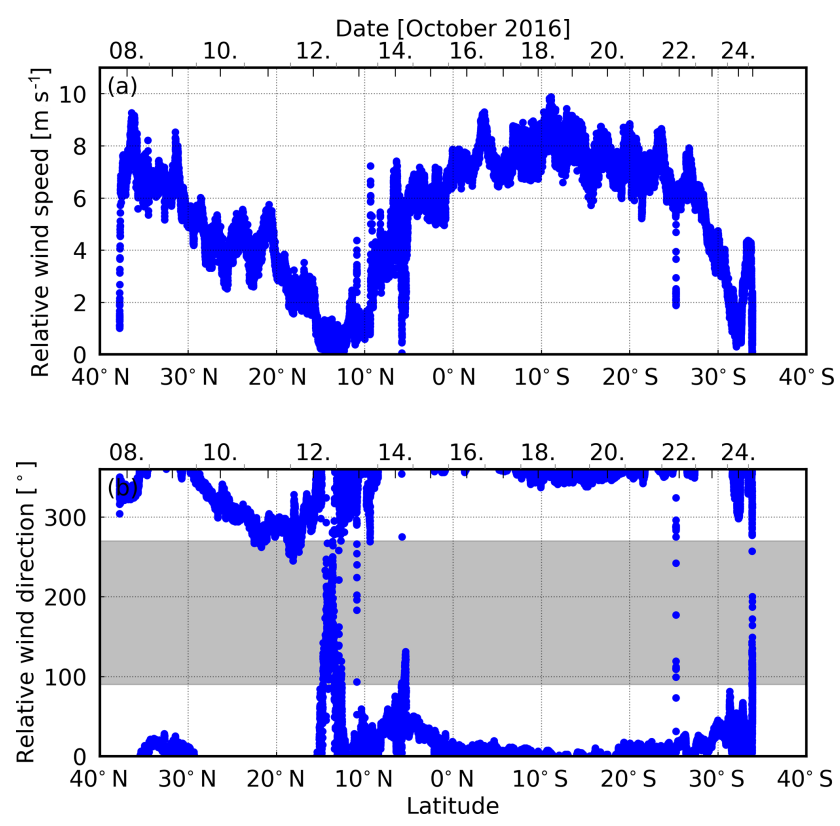

Figure 3. Relative (a) wind speed and (b) wind direction $\left(0^{\circ}\right.$ indicates headwinds) during the COPMAR campaign. Grey shaded measurements are excluded from the analysis in order to avoid possible contamination by the vessel's plume.

For the comparison with stratospheric $\mathrm{NO}_{2}$, data from satellite instruments (GOME-2A and GOME-2B) are used. To retrieve the latitudinal dependency of stratospheric $\mathrm{NO}_{2}$, a monthly mean for all measurements having SZAs smaller than $85^{\circ}$ is calculated for October 2016 using the DOAS fit settings from Richter et al. (2011). The satellite data are averaged over longitudes between 10 and $40^{\circ} \mathrm{W}$ and divided by stratospheric air mass factors (AMFs). Additionally, satellite observations for $\mathrm{HCHO}$ and $\mathrm{CHOCHO}$ are taken into 
account which are described in Alvarado et al. (2018) and Alvarado et al. (2019).

The measurement accuracy for satellite data is described in Boersma et al. (2004) and Lorente et al. (2017) as well as in Alvarado et al. (2014, 2019). Generally, over remote ocean areas, the uncertainty of tropospheric columns is dominated by errors in the stratospheric column (for $\mathrm{NO}_{2}$ ) and errors in the spectral fitting (Boersma et al., 2004). Boersma et al. (2004) found a relative uncertainty of up to $100 \%$ for $\mathrm{NO}_{2}$ in these areas. Thus, the satellite measurements over remote oceanic areas are close to the detection limit, making it impossible to compare single satellite measurements to the COPMAR results. Consequently, monthly means are used for the comparison. For spatial collocation of the measurements, the satellite pixels are averaged within a $200 \mathrm{~km}$ radius of the midday position of the ship.

\subsection{AERONET data}

The Maritime Aerosol Network (MAN; Smirnov et al., 2009) is a part of the AErosol RObotic NETwork (AERONET) project (Holben et al., 1998) and provides ship-borne aerosol optical depth (AOD) measurements from Microtops Sun photometers. These are handheld direct Sun measuring devices which are separated into five spectral channels (Smirnov et al., 2009). In the dataset of cruise MSM58/2, AODs at $380,440,500,675$, and $870 \mathrm{~nm}$ are available. The Ångström exponent is calculated from the channels at 440 and $870 \mathrm{~nm}$ (Smirnov et al., 2009). Details of the Microtops handheld Sun photometers and their uncertainties can be found in Ichoku et al. (2002), Morys et al. (2001), Porter et al. (2001), and Knobelspiesse et al. (2003, 2004). In the following, the AOD at $440 \mathrm{~nm}$ and the Ångström exponent are used for comparison with our data.

\subsection{MOZART-4 CTM}

The 4-D fields of $\mathrm{HCHO}$ and $\mathrm{CHOCHO}$ concentrations are needed as a priori information for the calculation of VCDs for both MAX-DOAS and satellite data (Sect. 3.7). These a priori information have been taken from the Model for OZone and Related chemical Tracers version 4 (MOZART4; Emmons et al., 2010) model output (available at https: //www.acom.ucar.edu/wrf-chem/mozart.shtml, last access: 17 April 2018). The model data have 6-hourly temporal and $\sim 1.9^{\circ} \times 2.5^{\circ}$ horizontal resolution. We further used these model data for the interpretation of our results (Sects. 4.2 and 4.3). For the comparison, the model data are linearly interpolated in time on the cruise track.

\subsection{FLEXPART}

FLEXPART is a Lagrangian dispersion and transport model which can be used to simulate atmospheric transport of air parcels (https://www.flexpart.eu/, last access: 29 September 2018; Stohl et al., 1998, 2005; Stohl and Thomson,
1999). Here, backward-in-time simulations (Seibert and Frank, 2004) are used to determine potential source regions of trace gas enhancements which were observed during $3 \mathrm{~d}$ during the cruise. The simulations were driven by ECMWF IFS (version CY41R2) wind fields at a horizontal resolution of $0.2^{\circ}$ and a temporal resolution of $1 \mathrm{~h}$. Backward simulations started at altitudes of 20, 500, 1000, 1500, 2000, 2500, $3000,3500,4000,4500$, and $5000 \mathrm{~m}$ above the ship's location at hourly intervals between $\sim$ 11:00 and $\sim$ 15:00 UTC, coinciding with the measurement times. For each model run, 2 million individual air parcels were followed backwards in time for 2-4d; the simulated air tracer did not undergo any deposition or other loss processes.

\subsection{FINN}

The Fire INventory from NCAR (National Center for Atmospheric Research; FINN) is a dataset providing daily global emissions of trace gases and particles from biomass burning at $1 \mathrm{~km}$ resolution (Wiedinmyer et al., 2011). For this inventory, satellite observations of active fires from MODIS are used. The emissions are calculated by using land cover type, emission factors, and the estimated fuel loadings. In our analysis, we consider fires on the days before and after the day with high FLEXPART emission sensitivity to the surface, in order to account for uncertainties in fire detection.

\subsection{DOAS analysis}

The spectra measured by the Avantes instrument (see Sect. 3.1) have been analysed using the differential optical absorption spectroscopy (DOAS; Platt and Stutz, 2008; Burrows et al., 2011) technique which is based on the BeerLambert law and describes the spectral attenuation of the initial intensity $\left(I_{0}\right)$ of light due to extinction along the light path $s$ :

$I(\lambda, s)=I_{0} \exp (-\sigma(\lambda) \rho s)$.

Here, $\lambda$ is the wavelength, $\sigma$ the absorption cross section, $I$ the reduced intensity, and $\rho$ the absorber concentration. This method can be used for ground-based as well as for satellite data, and for wavelengths in the ultraviolet and visible spectral ranges. The main result of the DOAS analysis is the integrated concentration of trace gases $\rho(s)$ along the effective light path $s$, the so-called slant column density (SCD; Platt and Stutz, 2008; Burrows et al., 2011):

$\mathrm{SCD}=\int \rho(s) \mathrm{d} s$.

This quantity depends on the light path which is influenced by the SZA, the relative azimuth angle, the viewing direction of the instrument, and the viewing conditions. Therefore, a rough estimation of the absorber altitude is possible, using SCDs from different elevation angles due to the scan angle dependency of the light path. For pollution close to the 
ground, the highest SCDs are expected for the lowest elevation angle, whereas for absorbers in elevated layers, the highest SCDs are expected at a higher elevation angle. For better interpretation, the SCDs are converted into VCDs, which are the integral of the trace gas concentration from the surface to the top of the atmosphere (TOA) along the altitude $z$ (Platt and Stutz, 2008; Burrows et al., 2011):

$\mathrm{VCD}=\int_{0}^{\mathrm{TOA}} \rho(z) \mathrm{d} z$.

For MAX-DOAS measurements, $I_{0}$ is usually a zenith sky measurement. Therefore, the derived quantities are differential values (differential SCD, dSCD), which has to be considered in the analysis. The sensitivity of the measurement to an absorber varies with altitude; this is expressed by the so-called box air mass factor (BAMF; Burrows et al., 2011), which is defined as $\mathrm{BAMF}_{i}=\mathrm{SCD}_{i} / \mathrm{VCD}_{i}$ for an atmospheric layer $i$. BAMFs are calculated by radiative transfer models (here SCIATRAN; Rozanov et al., 2014), which take into account the viewing geometry and environmental effects (Platt and Stutz, 2008). The total AMF can be retrieved by using the BAMF and the trace gas concentration in the individual layers:

$\mathrm{AMF}=\sum_{i=0}^{\mathrm{TOA}} \mathrm{BAMF}_{i} \times \frac{\mathrm{VCD}_{i}}{\mathrm{VCD}}$

$\mathrm{VCD}_{i}$ is the vertical distribution of the trace gases taken from the MOZART-4 model. The differential AMF (dAMF) is the difference between the AMF of the individual measurement and the AMF of the zenith sky reference measurement $\left(\mathrm{dAMF}=\mathrm{AMF}_{\text {meas }}-\mathrm{AMF}_{\text {ref }}\right)$. By applying the $\mathrm{dAMF}$, the dSCD can be converted to VCD:

$\mathrm{VCD}=\frac{\mathrm{dSCD}}{\mathrm{dAMF}}$

\subsection{DOAS-fit settings}

\subsubsection{Factors influencing MAX-DOAS retrievals}

The results of the DOAS analysis can be influenced by different effects. The instrument was mounted on the RV Maria S. Merian, and therefore a correction of the scan angle for the ship's roll angle is applied. This can lead to a mispointing of the scan angle. Because ship movement data at high resolution are used for the correction, this error is minimised.

The choice of reference spectrum is also important for the detection of trace gases. There are different options for reference spectra, for example, a sequential zenith sky reference spectrum, a daily noon zenith sky reference spectrum, or a fixed zenith sky reference spectrum for the full campaign. In this study, the trace gases are expected to be in elevated layers. Furthermore, satellite measurements indicate that they depend on latitude (see Fig. 1). For both cases, a fixed reference spectrum is needed as otherwise the trace gas signal might not be observable because elevated layers contribute to both horizon and zenith sky measurements in a similar way. Nevertheless, this choice does not impair the detectability of pollution located in the boundary layer. An important criterion for the choice of the fixed reference spectrum is that this spectrum is not affected by the elevated layer.

Each MAX-DOAS measurement is influenced by a systematic and a random error (Irie et al., 2011; Takashima et al., 2012). The random error can be estimated from the residual of the fitted trace gases (Takashima et al., 2012). However, also systematic errors can be found in the residual such as imperfectly resolved cross sections. Furthermore, Boersma et al. (2004) and Takashima et al. (2012) showed that the temperature dependency of the cross section also leads to systematic errors in the retrieved SCD. For example, for $\mathrm{NO}_{2}$, it is on the order of $0.4 \% \mathrm{~K}^{-1}$ (Takashima et al., 2012). For the vertical columns, the errors are on the order of $15 \%$ to $20 \%$ (Takashima et al., 2012; Peters et al., 2012).

The measurements were taken at low latitudes over the ocean, which led to strong water vapour absorption. This strong absorption, in combination with a imperfectly resolved water vapour cross section, can introduce problems in the fitting procedure. Therefore, the mean residual is used as an additional pseudo-cross-section for $\mathrm{CHOCHO}$ retrievals (see Sect. 3.8.4). Furthermore, the strong $\mathrm{H}_{2} \mathrm{O}$ absorption could contribute to interferences with weak absorbers. In this case, the differences should be reduced/enhanced for higher/lower elevation angles, respectively. However, this is not observed (compare Sect. 4).

The detection limit for the DOAS method for ship-based measurements depends on the trace gas and on the instrument. In this study, the detection limit is calculated for each trace gas individually with the method from Sinreich et al. (2010). They analysed CHOCHO as well and defined the detection limit as twice the root mean square (rms) of the fit residual divided by the strongest peak of the convoluted differential cross section. For the three analysed trace gases, the resulting detection limits are discussed in Sect. 3.8.2-3.8.4.

\subsubsection{Stratospheric $\mathrm{NO}_{2}$}

For the evaluation of the instrument setup, stratospheric $\mathrm{NO}_{2}$ is used, which is well known from previous studies such as Peters et al. (2012), Kreher et al. (1995), and Senne et al. (1996). For this $\mathrm{NO}_{2}$ retrieval, a fitting window from 450 to $490 \mathrm{~nm}$ is used. Absorption cross sections for $\mathrm{NO}_{2}$ (Vandaele et al., 1998) at $220 \mathrm{~K}$ and orthogonalised to this cross section at $298 \mathrm{~K}$ are used to account for the stratosphere and the troposphere, respectively. Furthermore, an $\mathrm{O}_{3}$ (Serdyuchenko et al., 2014; Gorshelev et al., 2014) cross section at $223 \mathrm{~K}$ with an $\mathrm{I}_{0}$ correction of $10^{20}$ molec $\mathrm{cm}^{-2}$ (Platt et al., 1997; Richter, 1997) is included in the fit. Additionally, cross sections for $\mathrm{O}_{4}$ (Thalman and Volkamer, 2013) and $\mathrm{H}_{2} \mathrm{O}$ (Roth- 


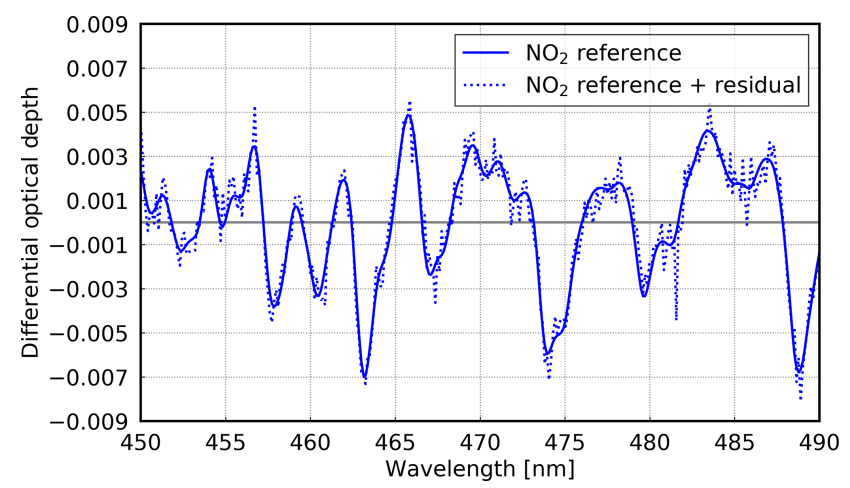

Figure 4. Example of a stratospheric $\mathrm{NO}_{2}$ fit for 14 October 2016 at 06:58 UTC (latitude: $\sim 7.4^{\circ} \mathrm{N}$; longitude: $\sim 17.8^{\circ} \mathrm{W}$ ). Both are shown, the reference scaled with the SCD as well as the scaled reference plus the residual. Zenith sky measurement with a SCD of $3.99 \times 10^{16}$ molec $\mathrm{cm}^{-2}$ and a rms of $6.9 \times 10^{-4}$ at $90.9^{\circ} \mathrm{SZA}$.

man et al., 2010), and a cross section to correct the Ring effect (Vountas et al., 1998) are included in the analysis, along with a fifth-order polynomial. Figure 4 shows an example fit for stratospheric $\mathrm{NO}_{2}$.

A fixed reference spectrum measured on 17 October 2016 at 12:20 UTC and $4.03^{\circ} \mathrm{SZA}$ is used to analyse the data. On this day, the ship was close to the Equator $\left(\sim 9.6^{\circ} \mathrm{S}\right)$ with negligible tropospheric $\mathrm{NO}_{2}$ (known from MAX-DOAS measurements analysed with a sequential zenith sky reference spectrum and satellite observations) and good weather conditions. The retrieved dSCDs for $\mathrm{NO}_{2}$ are converted into VCDs by using AMF calculated at a wavelength of $470 \mathrm{~nm}$. To analyse stratospheric $\mathrm{NO}_{2}$, only zenith sky measurements with a SZA smaller than $92^{\circ}$ are used.

For the conversion into total $\mathrm{VCD}$, a reference $\mathrm{VCD}$ $\left(\mathrm{VCD}_{\text {ref }}\right)$ is calculated as follows:

$$
\begin{aligned}
\mathrm{VCD}_{\text {ref }} & =\frac{\mathrm{VCD}_{\mathrm{AM}}+\mathrm{VCD}_{\mathrm{PM}}}{2} \\
& =\frac{\mathrm{dSCD}_{\mathrm{AM}}+\mathrm{dSCD}_{\mathrm{PM}}}{2 \times\left(\mathrm{AMF}_{88^{\circ}}-\mathrm{AMF}_{\mathrm{ref}}\right)} \\
& \approx 1.97 \times 10^{15} \mathrm{molec} \mathrm{cm}^{-2},
\end{aligned}
$$

with the assumption, that the reference spectrum is at noon and $\mathrm{VCD}_{\text {ref }}$ is the mean value of the morning $\left(\mathrm{VCD}_{\mathrm{AM}}\right)$ and evening value (VCDPM), both taken at $\mathrm{SZA}=88^{\circ}$. The AMFs are calculated by using the radiative transfer model SCIATRAN (Rozanov et al., 2014): $\mathrm{AMF}_{\text {ref }}=\operatorname{AMF}\left(10^{\circ}\right)=$ 1.11 and $\operatorname{AMF}\left(88^{\circ}\right)=12.99$. Afterwards, a reference $\mathrm{SCD}$ $\left(\mathrm{SCD}_{\text {ref }}\right)$ can be calculated:

$\mathrm{SCD}_{\text {ref }}=\mathrm{AMF}_{\text {ref }} \times \mathrm{VCD}_{\text {ref }} \approx 2.14 \times 10^{15}$ molec cm $^{-2}$,

which is added to the dSCD to retrieve total SCD:

$\mathrm{SCD}=\mathrm{dSCD}+\mathrm{SCD}_{\text {ref }}$

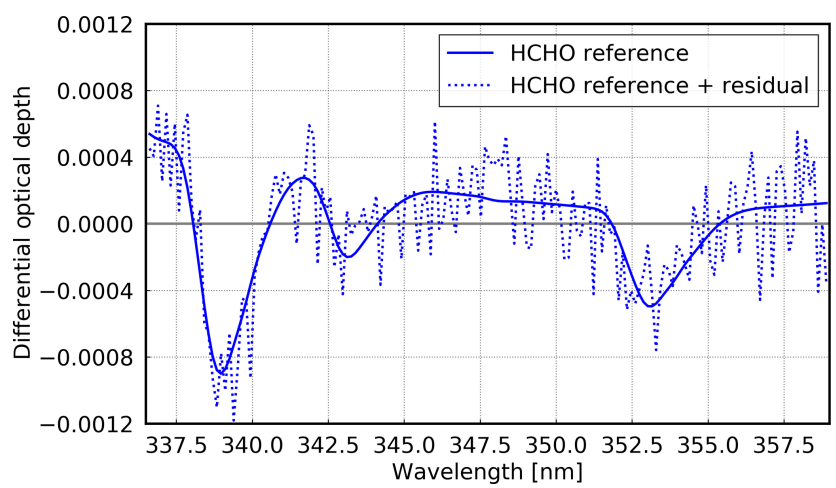

Figure 5. Example of a $\mathrm{HCHO}$ fit for 13 October 2016 at 14:38 UTC (latitude: $\sim 10.1^{\circ} \mathrm{N}$; longitude: $\sim 19.8^{\circ} \mathrm{W}$ ). The SCD is $2.52 \times 10^{16}$ molec cm ${ }^{-2}$ with a rms of $2.2 \times 10^{-4}$ at $29.46^{\circ} \mathrm{SZA}$ and a viewing angle of $15^{\circ}$.

After the conversion into total VCDs, the latitudinal dependency and the diurnal cycle of stratospheric $\mathrm{NO}_{2}$ are calculated. The longest light path in the stratosphere, and thus the highest sensitivity to stratospheric $\mathrm{NO}_{2}$, can be found during twilight. Therefore, measurements between $88^{\circ}$ and $92^{\circ}$ SZA are used for both morning and evening measurements for the analysis of the latitudinal dependency of stratospheric $\mathrm{NO}_{2}$. For the calculation of the stratospheric diurnal cycle, half-hour binned values are calculated, because of the higher signal-to-noise ratio compared to the single measurements.

The observed stratospheric $\mathrm{NO}_{2}$ values are well above the detection limit. The mean rms is $3.5 \times 10^{-4}$ and the strongest convoluted differential peak of the $\mathrm{NO}_{2}$ cross section $\left(1.4 \times 10^{-19}\right)$ which leads to an estimated detection limit of $4.8 \times 10^{15}$ molec cm $^{-2}$ for dSCDs (Sect. 3.7). For large SZAs with an AMF of around 15, the detection limit for VCDs is therefore $3.2 \times 10^{14}$ molec $\mathrm{cm}^{-2}$.

\subsubsection{Formaldehyde}

For the HCHO retrieval, a fitting window from 336.5 to $359 \mathrm{~nm}$ is used. Absorption cross sections for $\mathrm{HCHO}$ at $297 \mathrm{~K}$ (Meller and Moortgat, 2000), $\mathrm{O}_{3}$ (Serdyuchenko et al., 2014 ) at $223 \mathrm{~K}$ and orthogonalised $243 \mathrm{~K}$, as well as $\mathrm{NO}_{2}$ at $298 \mathrm{~K}$ (Vandaele et al., 1998) are used. For the latter two gases, an $\mathrm{I}_{0}$ correction (Aliwell et al., 2002) of $10^{20}$ and $10^{17} \mathrm{molec}^{-2}$ is applied, respectively. Additional cross sections are $\mathrm{O}_{4}$ (Thalman and Volkamer, 2013), BrO at $223 \mathrm{~K}$ (Fleischmann et al., 2004), as well as a cross section to correct the Ring effect (Vountas et al., 1998) and a polynomial of degree 5. Furthermore, the mean residual of the whole cruise is included as additional cross sections to improve the fit results. By including this additional cross section, the fit rms reduces by approximately $50 \%$ (not shown). Figure 5 shows an example fit for $\mathrm{HCHO}$. 
As for the case of stratospheric $\mathrm{NO}_{2}$, also for $\mathrm{HCHO}$ a fixed reference spectrum is used. The reference spectrum is from 23 October $2016\left(\sim 29.2^{\circ} \mathrm{S}\right)$ around noon. This date was chosen because of low HCHO content in the overhead column (expected from satellite observations), whereas closer to the Equator, higher $\mathrm{HCHO}$ values would be expected. For the conversion to VCDs, dAMF were calculated at the wavelength $338 \mathrm{~nm}$ as shown in Eq. (5).

Our measurements show HCHO dSCDs consistently above the detection limit. The measurements have a mean rms of $2.9 \times 10^{-4}$, which leads to a detection limit of $\sim 2.2 \times 10^{15} \mathrm{molec} \mathrm{cm}^{-2}$ for daily mean dSCDs, depending on the number of measurements per day. Applying a dAMF of 1.1 (representative of $30^{\circ}$ elevation angle; see also Sect. 3.7), this translates to a detection limit of $\sim 1.9 \times 10^{15}$ molec cm $^{-2}$ in the VCDs.

For the analysis, only measurements at $\mathrm{SZA}<70^{\circ}$ are used, because for larger SZA the measurement uncertainty increases. HCHO has a global background due to the oxidation of $\mathrm{CH}_{4}$ (Sect. 1). Therefore, the overhead column from the reference measurement needs to be considered for the conversion into total VCDs, which is done by adding the simulated column $\left(\mathrm{VCD}_{\text {Model }}=3.7 \times 10^{15} \mathrm{molec} \mathrm{cm}^{-2}\right)$ from the MOZART-4 data at the location of the reference measurement to the VCD:

$\mathrm{VCD}_{\text {total }}=\mathrm{VCD}+\mathrm{VCD}_{\text {Model }}$

\subsubsection{Glyoxal}

The CHOCHO fitting window is from 433 to $460 \mathrm{~nm}$ with a polynomial degree of 4 . Absorption cross sections are CHOCHO (Volkamer et al., 2005) and $\mathrm{O}_{3}$ (Bogumil et al., 2003) at $223 \mathrm{~K}$ with an $\mathrm{I}_{0}$ correction of $10^{20}$ molec $\mathrm{cm}^{-2}$. Furthermore, $\mathrm{NO}_{2}$ cross sections (Vandaele et al., 1998) at $298 \mathrm{~K}$ with $\mathrm{I}_{0}$ correction of $10^{17} \mathrm{molec} \mathrm{cm}^{-2}$ and at $220 \mathrm{~K}$ orthogonalised to $298 \mathrm{~K}$, an $\mathrm{O}_{4}$ cross section (Thalman and Volkamer, 2013) at $293 \mathrm{~K}$, a $\mathrm{H}_{2} \mathrm{O}$ cross section (Rothman et al., 2010) at $296 \mathrm{~K}$ with an $\mathrm{I}_{0}$ correction of $10^{24}$ molec $\mathrm{cm}^{-2}$, as well as a cross section to correct for the Ring effect (Vountas et al., 1998) are included in the fit. The fit residual shows structures which are related to strong water vapour absorption over the ocean and possible missing peaks in the water cross section (not shown).

To improve the fit residual, two additional cross sections were tested: an alternative $\mathrm{H}_{2} \mathrm{O}$ cross section (Polyansky et al., 2018) and a mean residual as an additional cross section. The alternative $\mathrm{H}_{2} \mathrm{O}$ cross section did not reduce the fit residual, and therefore it is not used here. The mean residual was calculated for all measurements during the cruise and the fit was repeated including this mean residual as additional pseudo-absorber. This additional cross section clearly improved the fit residual, and therefore this pseudo-absorber is used in the following. Figure 6 shows an example fit for CHOCHO.

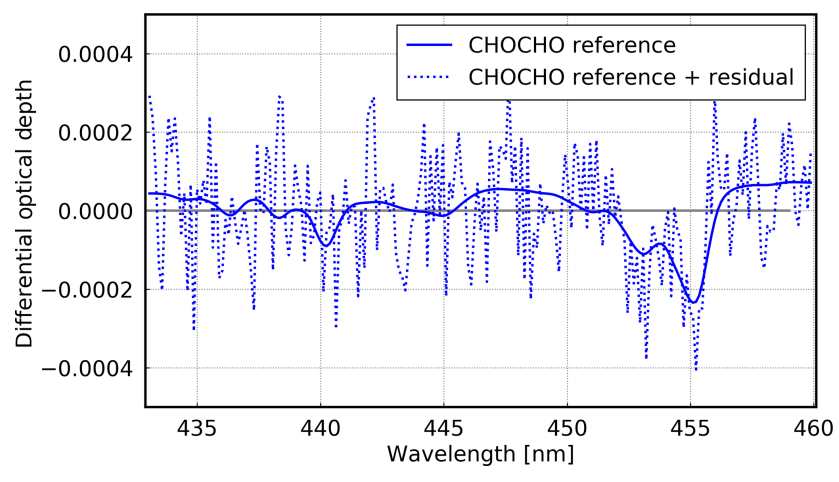

Figure 6. Example of a $\mathrm{CHOCHO}$ fit for 13 October 2016 at 11:33 UTC (latitude: $\sim 10.8^{\circ} \mathrm{N}$; longitude: $\sim 20.0^{\circ} \mathrm{W}$ ). The SCD is $6.17 \times 10^{14}$ molec cm $^{-2}$ with a rms of $1.3 \times 10^{-4}$ at $29.75^{\circ} \mathrm{SZA}$ and a viewing angle of $7^{\circ}$.

As for HCHO, a reference spectrum from 23 October 2016 around noon was chosen. Also for CHOCHO, low overhead columns are expected in this area. Since background concentrations of $\mathrm{CHOCHO}$ are not expected, no global background value has to be added. For the conversion into VCDs, AMFs were calculated at the wavelength $433 \mathrm{~nm}$ (see Eq. 5), and only measurements at SZAs $<70^{\circ}$ are used in order to limit noise occurring at low intensities.

Our analysis of the MAX-DOAS measurements yields CHOCHO dSCDs which are often below the detection limit. The rms is on the order of $1.6 \times 10^{-4}$, resulting in a detection limit of $\sim 1.7 \times 10^{14} \mathrm{molec} \mathrm{cm}^{-2}$ for daily averages of the dSCDs, depending on the number of measurements (Fig. 11). Applying a dAMF of 1.2 (representative of $30^{\circ}$ elevation angle; see also Sect. 3.7), this translates to a detection limit of $\sim 1.4 \times 10^{14}$ molec cm $^{-2}$ in the VCDs.

\section{Results}

\subsection{Evaluation of stratospheric $\mathrm{NO}_{2}$}

To demonstrate the performance of the instrument setup, we analysed the diurnal and latitudinal variation of stratospheric $\mathrm{NO}_{2}$ and compared our results with satellite data and previous studies. The diurnal cycle of stratospheric $\mathrm{NO}_{2}$ is closely related to the photolysis of the reservoir species $\mathrm{N}_{2} \mathrm{O}_{5}$ (Solomon et al., 1986). During daylight, $\mathrm{NO}_{2}$ increases as result of $\mathrm{N}_{2} \mathrm{O}_{5}$ photolysis, whereas at night, $\mathrm{N}_{2} \mathrm{O}_{5}$ increases and $\mathrm{NO}_{2}$ is removed. Thus, it has a minimum in the morning, followed by a linear increase. As shown by Peters et al. (2012), this diurnal cycle can be observed over remote oceanic areas, where the stratospheric signal is usually not impaired by the presence of tropospheric $\mathrm{NO}_{2}$. On cruise MSM58/2, such a diurnal cycle could also be observed, which is exemplarily shown for 15 October 2016 in Fig. 7. On that day, the linear increase during daytime amounted to $7.31 \times 10^{13} \mathrm{molec} \mathrm{cm}^{-2} \mathrm{~h}^{-1}\left(\sim 2.5^{\circ} \mathrm{N}, \sim 13.9^{\circ} \mathrm{W}\right)$. Pre- 


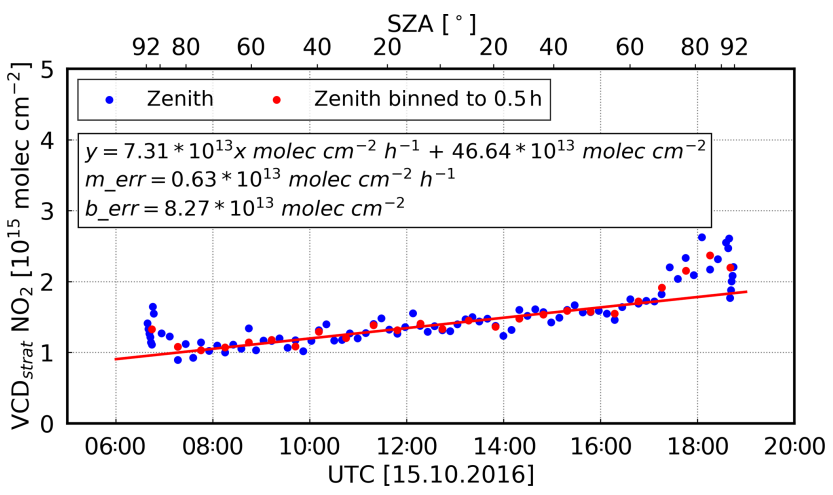

Figure 7. The diurnal cycle of stratospheric $\mathrm{NO}_{2}$ (15 October 2016; latitude: $\sim 2.5^{\circ} \mathrm{N}$; longitude: $\left.\sim 13.9^{\circ} \mathrm{W}\right)$. In red, the data are binned to $0.5 \mathrm{~h}$ values to improve the signal-to-noise ratio. Also shown is the regression line which represents a linear increase during the day. The data are shown for SZAs smaller than $92^{\circ}$. Furthermore, the errors of the slope $\left(m_{\mathrm{err}}\right)$ and of the intercept $\left(b_{\mathrm{err}}\right)$ are presented.

vious studies found similar results, e.g. Peters et al. (2012), with an increase of $8.7 \times 10^{13} \mathrm{molec} \mathrm{cm}^{-2} \mathrm{~h}^{-1}$ for the tropics and Gil et al. (2008) with an increase of $6 \times 10^{13}$ molec $\mathrm{cm}^{-2} \mathrm{~h}^{-1}$ for the subtropics.

The diurnal cycle of stratospheric $\mathrm{NO}_{2}$ depends on the latitude, with a smaller increase in the tropics and a stronger increase towards the midlatitudes, as shown in Fig. 8. The presented morning and evening MAX-DOAS values (averaged over all measurements with SZAs between 88 and $92^{\circ}$ ) approximately correspond to the first and last red dots in Fig. 7, respectively. They both show a local minimum near the Equator and increase towards the midlatitudes.

The morning MAX-DOAS values range from $2.0 \times 10^{15} \mathrm{molec} \mathrm{cm}^{-2}$ at $32.8^{\circ} \mathrm{N}$ to $1.2 \times 10^{15} \mathrm{molec} \mathrm{cm}^{-2}$ close to the Equator and increase again in the Southern Hemisphere to $2.3 \times 10^{15}$ molec $\mathrm{cm}^{-2}$ at $33.7^{\circ} \mathrm{S}$. On the other hand, the evening MAX-DOAS values are higher $\left(3.4 \times 10^{15} \mathrm{molec} \mathrm{cm}^{-2}\right.$ at $35.4^{\circ} \mathrm{N}$ to $2.0 \times 10^{15} \mathrm{molec} \mathrm{cm}^{-2}$ close to the Equator and $3.5 \times 10^{15} \mathrm{molec} \mathrm{cm}^{-2}$ at $32.8^{\circ} \mathrm{S}$ ). This "U" shape can also be observed in the satellite measurements. Given the 09:30 local time (which corresponds to $\sim$ 11:00 UTC) overpass time of both GOME-2 instruments, one would expect that the satellite values are close to the morning MAX-DOAS values. Taking measurement uncertainties into account, this behaviour can indeed be found for the GOME-2B data. However, the GOME-2A measurements are slightly higher than the observed morning MAX-DOAS values, which is probably related to the degradation of the instrument (Dikty and Richter, 2011). The uncertainties for the retrieved MAX-DOAS measurements are calculated by error propagation using the fitting error and the assumed AMF uncertainty of \pm 1 . The uncertainty in $\mathrm{VCD}_{\text {ref }}$ has been neglected (an assumed uncertainty of $30 \%$ in $\mathrm{VCD}_{\text {ref }}$ amounts to a value of $0.59 \times 10^{15} \mathrm{molec} \mathrm{cm}^{-2}$, which

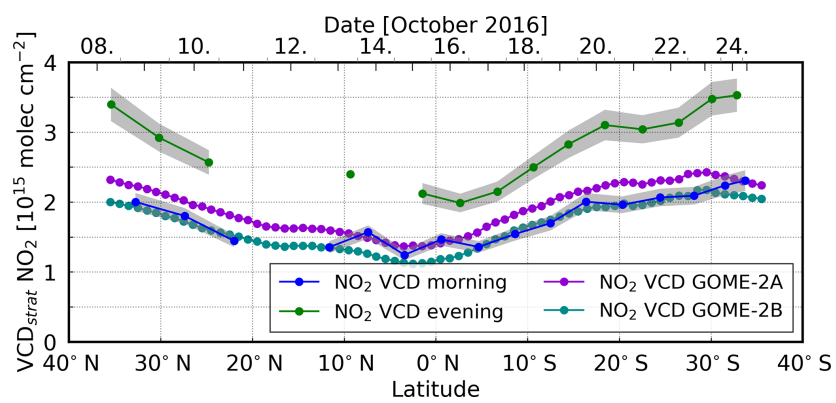

Figure 8. The latitudinal dependency (from north to south) of stratospheric $\mathrm{NO}_{2}$ over the Atlantic Ocean shows a local minimum near the Equator and an increase towards the midlatitudes. MAXDOAS morning and evening values have been averaged over all zenith sky measurements for SZAs between 88 and $92^{\circ}$. The colourshaded areas indicate the errors of the measurements.

corresponds to an uncertainty of $0.65 \times 10^{15}$ molec $\mathrm{cm}^{-2}$ for the $\mathrm{SCD}_{\text {ref }}$, resulting in a negligibly small uncertainty of $0.05 \times 10^{15}$ molec $\mathrm{cm}^{-2}$ for twilight measurements).

Our results for stratospheric $\mathrm{NO}_{2}$ are in good agreement with previous studies from Kreher et al. (1995) and Senne et al. (1996), especially in the Northern Hemisphere and across the Equator. In the Southern Hemisphere (at $30^{\circ} \mathrm{S}$ ), however, the values reported by Kreher et al. (1995) and Senne et al. (1996) are significantly higher than our measurements presented here, with values of approximately $3 \times 10^{15}$ molec cm ${ }^{-2}$ (morning) and $5 \times 10^{15}$ molec cm$^{-2}$ (evening). This could be related to either intra-annual (our measurements were taken a few weeks earlier in the year compared to the two previous studies) or interannual variability. Kreher et al. (1995) and Senne et al. (1996) analysed measurements from 1990 and 1993, respectively. These measurements differ by approximately $1 \times 10^{15} \mathrm{molec} \mathrm{cm}^{-2}$ at $30^{\circ}$ N. Furthermore, Kreher et al. (1995) showed that the values differ for higher latitudes between the individual years. In the Southern Hemisphere, we observe a stronger increase towards the midlatitudes compared to the Northern Hemisphere, consistent with the findings by Kreher et al. (1995) and, for the Pacific Ocean, by Peters et al. (2012).

Overall, the instrument performed well as the diurnal cycle and the latitudinal dependency of stratospheric $\mathrm{NO}_{2}$ are clearly visible in our measurements and our results agree with previous studies as well as satellite data. Therefore, we are confident in the suitability of our measurements to analyse the weak absorbers ( $\mathrm{HCHO}$ and $\mathrm{CHOCHO}$ ).

\subsection{Formaldehyde}

The latitudinal variation of daily mean MAX-DOAS HCHO dSCDs observed during the cruise shows enhanced values in an elevated layer at both $\sim 10^{\circ} \mathrm{N}$ and $\sim 5^{\circ} \mathrm{S}$. This coincides with the area of expected outflow from the African continent as seen in satellite measurements (Fig. 1a). Typically, the $\mathrm{HCHO}$ concentration in polluted areas is expected to be 


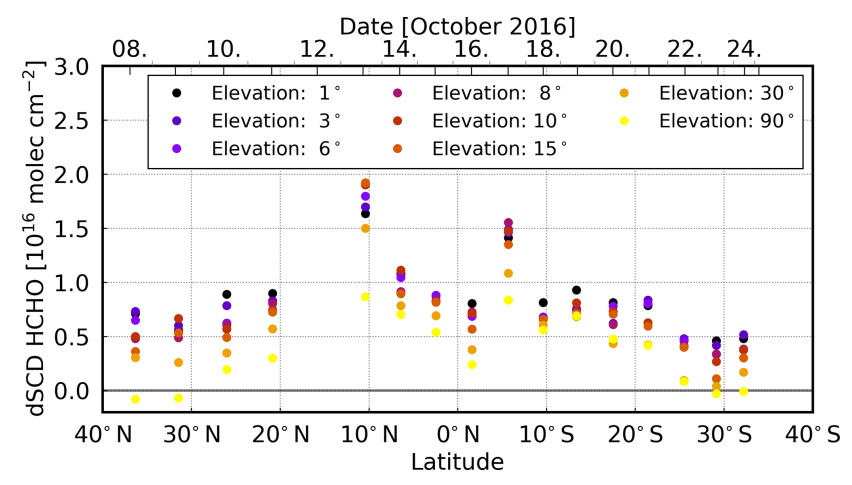

Figure 9. Daily mean HCHO dSCDs over the Atlantic Ocean over the course of the cruise (from north to south). Enhanced values in the areas of expected outflow show a different scan angle dependency.

highest close to the surface (De Smedt et al., 2008; Heckel et al., 2005) due to the primary emission sources of HCHO and rapid photochemical production from VOC precursors. Thus, also the highest dSCDs should be observed at low elevation angles near the sources. Figure 9 illustrates the daily mean HCHO dSCDs during the cruise at different elevation angles. During the cruise, whenever low HCHO columns $\left(\sim 0.5 \times 10^{16}\right.$ molec $\mathrm{cm}^{-2}$ for zenith sky measurements) are observed, the dSCDs are indeed highest at the lowest elevation angles.

Around $10^{\circ} \mathrm{N}$ and $5^{\circ} \mathrm{S}$ (on 13, 14, and 17 October, respectively), we observe enhanced $\mathrm{HCHO}$ values

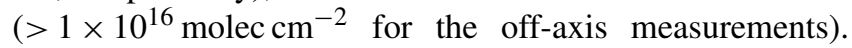
Here, the dSCDs are largest at higher elevation angles, which indicates that $\mathrm{HCHO}$ is predominantly located in an elevated layer. Still, the zenith sky measurements show the lowest values, but the other elevation angles are ordered differently than usual, with highest HCHO dSCD at elevation angles between 8 and $15^{\circ}$. This pattern is not only visible in the daily mean as depicted in Fig. 9 but can also be observed for the individual vertical scans (not shown here).

When converting the measured HCHO dSCD to VCDs (using the $30^{\circ}$ elevation angle and $\mathrm{HCHO}$ profiles from the MOZART-4 model), the values on 13, 14, and 17 October remain clearly enhanced (see Fig. 10a). At least the first region sampled on $13 / 14$ October $\left(\sim 10^{\circ} \mathrm{N}\right)$ indeed coincides with the area for which satellite observations regularly show enhanced HCHO values (compare Figs. 1a and 2). On these days, also MOZART-4 data are enhanced in the region. However, differences between the datasets are visible. On 13 October, MAX-DOAS and MOZART-4 data are higher than the satellite data. While on 14 October, MAX-DOAS and satellite data are slightly smaller than on 13 October, MOZART4 data are further increased. On 17 October $\left(5^{\circ} \mathrm{S}\right)$, there is no clear sign of a $\mathrm{HCHO}$ enhancement in the satellite and model data in contrast to MAX-DOAS measurements. These differences could be related to several reasons. The MAX-
DOAS data are measured on single days, whereas the satellite datasets are monthly means and MOZART-4 time series are interpolated on the cruise track. Thus, the differences between MAX-DOAS and satellite data could be explained by single, isolated outflow events on specific days, which are not distinguishable from background values in the monthly averaged satellite data. The interpolation of the model data could lead to differences between model and MAX-DOAS data as, for example, isolated events might not be represented in the model data. Furthermore, the satellite and model data are averages over larger areas which would dilute the magnitude of the measured or simulated values. Thus, comparing $\mathrm{HCHO}$ columns retrieved from OMI and GOME-2B radiances (Sect. 3.2) and integrated columns from simulated MOZART-4 profiles (Sect. 3.4; interpolated on the cruise track) to our MAX-DOAS VCDs, the results generally confirm the finding of enhanced $\mathrm{HCHO}$ satellite and model columns. The datasets show good agreements with correlation coefficients larger than 0.72 (Table 2).

The MAX-DOAS measurements are mostly higher than the satellite observations (Fig. 10a), which results in a slope larger than 1 (1.91, OMI and 1.24, GOME-2B) and a large offset for GOME-2B $\left(3.05 \times 10^{15}\right.$ molec cm $^{-2}$, GOME-2B and $0.01 \times 10^{15}$ molec $\mathrm{cm}^{-2}$, OMI) of the regression line (Table 2). These differences are clearly visible between 20 and $32^{\circ} \mathrm{N}$ (9-11 October) and between 10 and $22^{\circ} \mathrm{S}$ (1821 October; Fig. 10a), which have been measured in clean remote ocean areas with low pollution.

Compared to the MOZART-4 model values, the MAXDOAS observations are often higher, which can also be observed in a low slope of 0.68 . Close to the Equator, the values show good agreement in the area of expected pollution outflow which leads to a high correlation coefficient of 0.72 between the two datasets. However, the offset is also high between the two datasets $\left(4.82 \times 10^{15}\right.$ molec $\left.\mathrm{cm}^{-2}\right)$.

Several reasons can contribute to an enhancement in MAX-DOAS data. Large differences between the MAXDOAS and the satellite or model data are found over regions with low air pollution north and south of the Equator. In these areas, high measurement uncertainties can be found in the satellite data due to the low columns which might influence the retrieved satellite values. It is also possible that the model and satellite results underestimate the VCDs, because of the potentially localised nature of the enhancements (see also Sect. 5). Increased uncertainties in the MAX-DOAS data in this region can be ruled out, as the DOAS fit rms is nearly constant during the whole cruise (see Sect. 3.8.3). Furthermore, $\mathrm{H}_{2} \mathrm{O}$ interferences might contribute to the differences. In that case, the differences should be reduced/increased for higher/lower elevation angles, respectively. However, this can also be ruled out as a similar behaviour is visible for all viewing directions. Additionally, bad weather conditions can be ruled out, because the affected days of the MAX-DOAS measurements had different weather conditions (see Table 1), and an intensity filter 
Table 2. Correlation, slope, and intercept between HCHO MAX-DOAS and satellite measurements as well as model simulations. The values in brackets are the standard errors for slope and intercept.

\begin{tabular}{lrrr}
\hline & $\begin{array}{r}\text { Correlation } \\
\text { coefficient }\end{array}$ & Slope & $\begin{array}{r}\text { Intercept } \\
\left(10^{15} \mathrm{molec} \mathrm{cm}^{-2}\right)\end{array}$ \\
\hline OMI vs. MAX-DOAS & 0.79 & 1.91 & 0.01 \\
& & $(0.36)$ & $(1.84)$ \\
GOME-2B vs. MAX-DOAS & 0.72 & 1.24 & 3.05 \\
& & $(0.26)$ & $(1.48)$ \\
MOZART-4 vs. MAX-DOAS & 0.72 & 0.68 & 4.82 \\
& & $(0.15)$ & $(1.16)$ \\
\hline
\end{tabular}
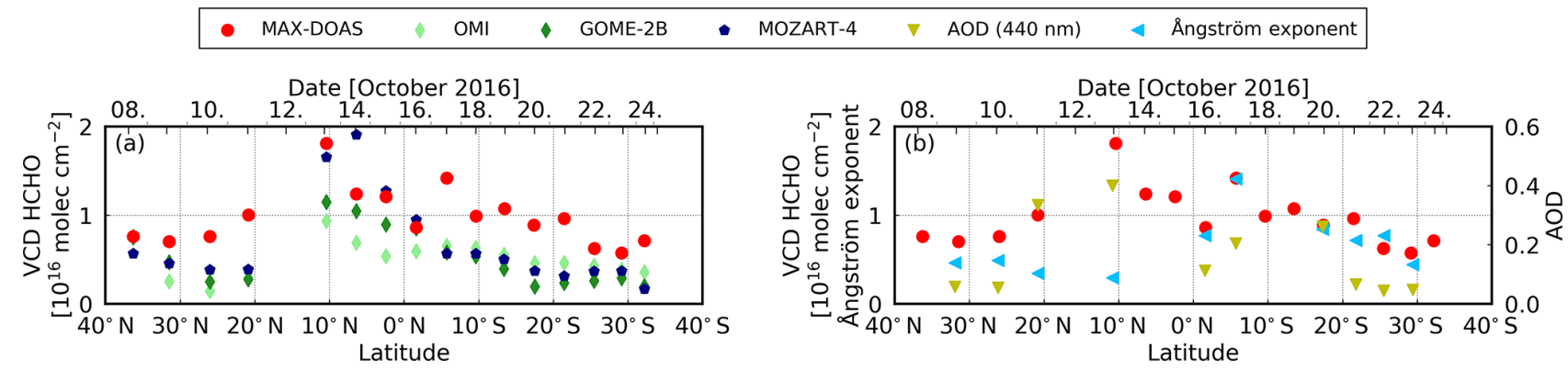

Figure 10. Daily mean HCHO VCDs over the Atlantic Ocean over the course of the cruise (from north to south). (a) Enhanced HCHO values can be observed in the area of expected outflow. Satellite observations and model values are also enhanced in this area. (b) The AOD and Ångström exponent from AERONET measurements are partly enhanced in these areas, depending on the source region.

was used to exclude poor viewing conditions (see Sect. 3.1). Similar conditions were also used for satellite values. Here, only measurements with geometric cloud fraction smaller 0.3 were included in the analysis.

The AMF could introduce the differences between the datasets. However, this seems unlikely as the MOZART-4 model is used for the AMF calculations for both MAXDOAS and satellite measurements, and this model does not show a similar behaviour to the MAX-DOAS measurements. For example, if the model underestimates/overestimates the total amount of $\mathrm{HCHO}$ in the atmosphere, this would in good approximation not change AMFs, and therefore the VCDs of both datasets are not influenced. Thus, no difference would be introduced between the satellite and MAXDOAS data. Possibly, the differences between the datasets can be related to the HCHO model profile if it would differ from the real atmospheric profile. On the one hand, the model could put the $\mathrm{HCHO}$ enhancement at the wrong altitude. This could lead to both an underestimation or an overestimation of the MAX-DOAS VCDs, depending on the profile and the SZA or relative azimuth angle, similar for satellite measurements. On the other hand, the model could miss an additional, elevated layer of transported HCHO or an additional layer close to the surface. During those days, the $\mathrm{HCHO}$ in the model is located at $\sim 3 \mathrm{~km}$ altitude, where the MAX-DOAS sensitivity is highest. Therefore, an additional layer of HCHO would reduce the MAX-DOAS AMF, lead- ing to a higher MAX-DOAS VCD; if located close to the surface, also the satellite VCD would increase. In this case, the difference between MAX-DOAS and satellite VCD would be reduced due to the stronger altitude dependence of the satellite BAMF compared to the MAX-DOAS BAMF. If the additional layer were located above the model elevated layer, the satellite AMF would increase due to the better visibility, leading to decreased satellite VCDs, further increasing the differences between satellite and MAX-DOAS VCDs. Additionally, aerosols could influence the AMFs leading to differences in satellite and MAX-DOAS VCD observations.

\subsection{Glyoxal}

The observed CHOCHO dSCDs are mostly higher at low elevation angles, again indicating that the trace gas is located close to the ground (Fig. 11). The measured dSCDs are mostly smaller than $0.2 \times 10^{15} \mathrm{molec} \mathrm{cm}^{-2}$, fluctuating around zero. Thus, the measurements are below the calculated detection limit (see Sect. 3.7). Nevertheless, enhanced CHOCHO dSCDs were observed on 13 and 14 October (around $10^{\circ} \mathrm{N}$ ) as for $\mathrm{HCHO}$, with a maximum value of about $\sim 0.30 \times 10^{15}$ molec $\mathrm{cm}^{-2}$ for 15 and $6^{\circ}$ elevation angle measurements (see Fig. 11). On these two days, the measurements are above the detection limit and the scan angle dependency is slightly different, which indicates that the observed $\mathrm{CHOCHO}$ is located in an elevated layer, albeit not as clearly as for $\mathrm{HCHO}$. On some days, the measurements for 
Table 3. Correlation, slope, and intercept between CHOCHO MAX-DOAS and satellite measurements as well as model simulations. The values in brackets are the standard errors for slope and intercept.

\begin{tabular}{lrrr}
\hline & $\begin{array}{r}\text { Correlation } \\
\text { coefficient }\end{array}$ & Slope & $\begin{array}{r}\text { Intercept } \\
\left(10^{15} \mathrm{molec} \mathrm{cm}^{-2}\right)\end{array}$ \\
\hline OMI vs. MAX-DOAS & 0.56 & 0.32 & $\begin{array}{r}-0.05 \\
(0.11)\end{array}$ \\
MOZART-4 vs. MAX-DOAS & 0.55 & 1.06 & $\begin{array}{l}0.03 \\
(0.29)\end{array}$ \\
& & $(0.03)$ \\
\hline
\end{tabular}

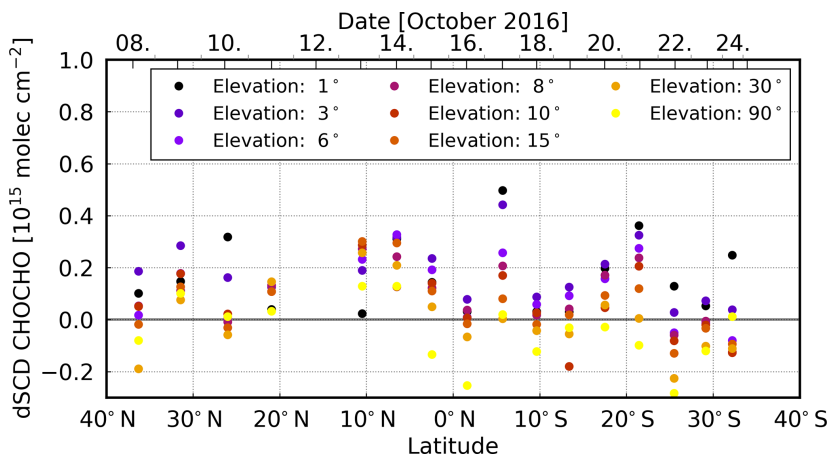

Figure 11. The latitudinal dependency (from north to south) of daily mean CHOCHO dSCDs over the Atlantic Ocean. On 13 and 14 October, a different scan angle dependency is shown.

lower elevation angles are above the detection limit (17 and 21 October). Here, $\mathrm{CHOCHO}$ might be located closer to the ground.

When converting the measured $\mathrm{CHOCHO}$ dSCDs to VCDs (again using the $30^{\circ}$ elevation angle and $\mathrm{CHOCHO}$ profiles from the MOZART-4 model), the values on 13 and 14 October remain enhanced (see Fig. 12). This region indeed coincides with the area for which satellite observations regularly show enhanced CHOCHO columns (see Fig. 1b). Comparing columns retrieved from OMI radiances and integrated from simulated MOZART-4 profiles (interpolated on the cruise track) to our MAX-DOAS VCDs, this generally confirms the finding of enhanced $\mathrm{CHOCHO}$ satellite and model columns. CHOCHO VCDs from all three datasets show enhanced values around $10^{\circ} \mathrm{N}$, while MAX-DOAS and MOZART-4 values further north and further south are close to zero. In comparison, OMI observations show enhanced CHOCHO columns throughout the tropics in Fig. 12. This behaviour could be explained by an elevated $\mathrm{CHOCHO}$ layer which is not represented in the model and cannot be detected by MAX-DOAS measurements due to their low sensitivity in the free troposphere. The enhanced values throughout the tropics are also represented in the slope of the regression line with 0.32 ; nevertheless, only a negligible offset of $-0.05 \times 10^{15} \mathrm{molec} \mathrm{cm}^{-2}$ was found (Table 3 ). The correlation between MAX-DOAS and OMI CHOCHO VCDs is 0.56 . The modelled MOZART-4 data are mostly close to or slightly higher than the observed MAX-DOAS values; in particular, the observed $\mathrm{CHOCHO}$ enhancements are less pronounced in our measurements than in the model data, resulting in a slope of the regression line of 1.06 with a high standard error of 0.29 , whereas the offset is small $\left(-0.06 \times 10^{15} \mathrm{molec} \mathrm{cm}^{-2}\right)$. Overall, the MOZART-4 and MAX-DOAS CHOCHO data have a correlation coefficient of 0.55 .

\subsection{Aerosol}

Around $10^{\circ} \mathrm{N}$ (13 October) the AERONET AOD (0.40) and the MAX-DOAS HCHO and CHOCHO are clearly enhanced in an elevated layer for the traces gases (Figs. 10b and 12b). Similar results for MAX-DOAS measurements were found at $6^{\circ} \mathrm{N}$ (14 October), where no AOD observations are available. At approximately $20^{\circ} \mathrm{N}$ (11 October), the AERONET AOD shows also slightly enhanced values (0.33). For the MAXDOAS measurements, the values are slightly increased for HCHO with the same scan angle dependency as expected for pollution close to the ground. Here, it is important to remember that for $\mathrm{CHOCHO}$ the values are below/close to the detection limit. On both days (11 and 13 October), the Ångström exponent is on the order of 0.3 . The classification of Toledano et al. (2007) shows that in this area the main aerosol type is desert dust, which agrees with the findings of Takemura et al. (2000), Ridley et al. (2012), Ichoku et al. (2004), and Schepanski et al. (2017).

At approximately $5^{\circ} \mathrm{S}$ (17 October), the relation between MAX-DOAS measurements, AOD, and Ångström exponent is slightly different. The AOD is 0.20 , with a high Ångström exponent of 1.41 indicating a different source than in the Northern Hemisphere. Here, the main aerosol type is on the edge between marine and continental aerosol, after the classification of Toledano et al. (2007). Because of the enhanced $\mathrm{HCHO}$ in an elevated layer, it might originate from continental sources.

At approximately $18^{\circ} \mathrm{S}$ (20 October), the AOD is increased with a value of 0.26 , and the Angström exponent has a value of 0.84 . However, $\mathrm{HCHO}$ and $\mathrm{CHOCHO}$ show no enhancement. On this day, a container vessel was sailing in front of RV Maria S. Merian and increased tropospheric 


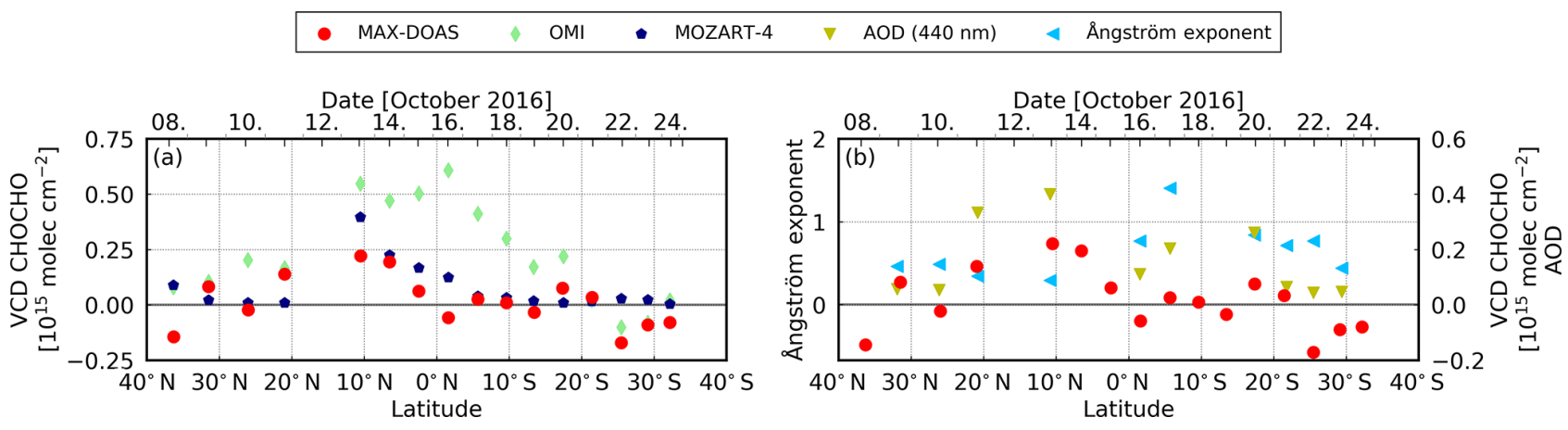

Figure 12. The latitudinal dependency (from north to south) of daily mean CHOCHO VCDs over the Atlantic Ocean. (a) Enhanced CHOCHO values can be observed in the area of expected outflow. As for HCHO, satellite observations and model values are enhanced in this area. (b) AOD from AERONET dataset is enhanced in this area. For this plot, a similar axis as for Fig. 10 is used.

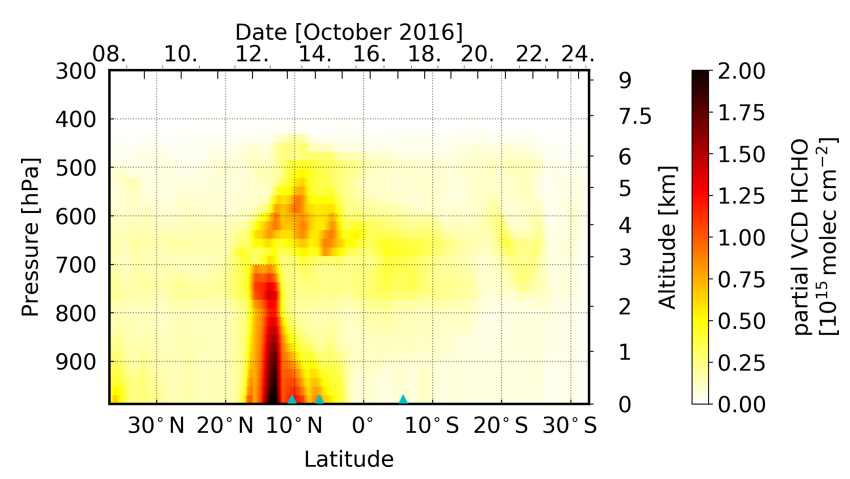

Figure 13. HCHO MOZART-4 profiles as used for VCDs calculations, interpolated on the cruise track (from north to south). The blue triangles on the bottom indicate the position of RV Maria S. Merian on the days with unusual scan angle dependency. For the calculation of the altitude, a mean temperature profile is used.

$\mathrm{NO}_{2}$ columns were observed with a clear scan angle dependency expected for pollution close to the surface (not shown). The main aerosol type classified after Toledano et al. (2007) is desert dust. The reason for the AOD enhancement might be that the air mass is strongly mixed with marine aerosols which were visible on the first days and the last days of the cruise. Thus, a mixture of exhaust and marine aerosols is observed, potentially leading to the desert dust classification.

\subsection{Model simulations}

MOZART-4 model simulations (Emmons et al., 2010) show elevated layers of enhanced $\mathrm{HCHO}$ and $\mathrm{CHOCHO}$ concentrations between $\sim 3000$ and $\sim 6000 \mathrm{~m}$ (Figs. 13 and 14, respectively), on 13, 14, and 17 October. On these days, the scan angle dependency of the measured dSCDs suggests the presence of an elevated layer of $\mathrm{HCHO}$ and $\mathrm{CHOCHO}$ and of only $\mathrm{HCHO}$, respectively. However, the model shows generally between $20^{\circ} \mathrm{N}$ and approximately $30^{\circ} \mathrm{S}$ increased values in an elevated layer, which cannot be confirmed by our measurements. On 13 and 14 October, the model addition-

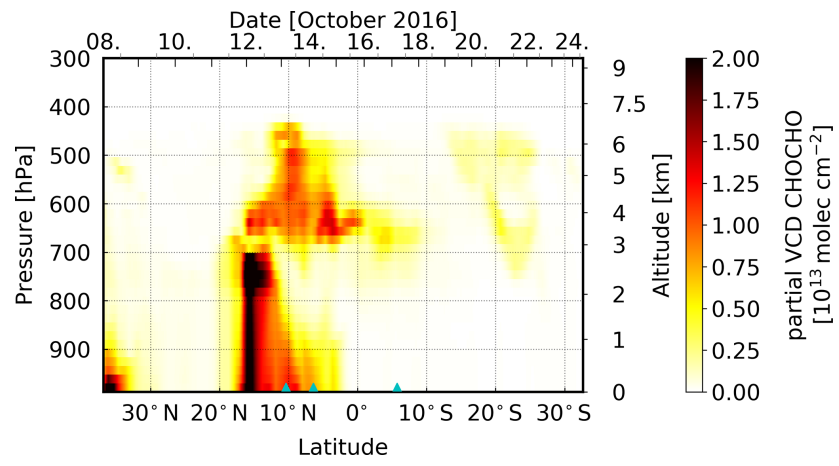

Figure 14. CHOCHO MOZART-4 profiles as used for VCD calculations, interpolated on the cruise track (from north to south). The blue triangles on the bottom indicate the position of RV Maria $S$. Merian on the days with unusual scan angle dependency. For the calculation of the altitude, a mean temperature profile is used.

ally shows enhanced VOC concentrations between the surface and approximately $2000 \mathrm{~m}$ altitude. This lower layer of high VOC concentrations could explain the overall higher dSCDs compared to the other days, probably indicating that the enhanced dSCDs measured on that day are only partly located in an elevated layer.

To further complement the interpretation of our results, we conducted backward simulations with the FLEXPART dispersion model (Stohl et al., 1998, 2005; Stohl and Thomson, 1999), following air masses from the position of the ship towards potential sources which are assumed to be in the lowest 500 or $1000 \mathrm{~m}$. For the VOC enhancements observed on 13 October, the simulated emission sensitivities indicate air masses originating from the Sahel and the more southerly forest, shrub-, grass-, and croplands (Mayaux et al., 2004; Fig. 15) were measured at the vessel. These areas are potential source regions for emissions of biogenic precursors of $\mathrm{HCHO}$ and CHOCHO. Furthermore, fires from the FINN dataset are shown in Fig. 15. Some of these fires were detected in the possible source regions which can also be a 

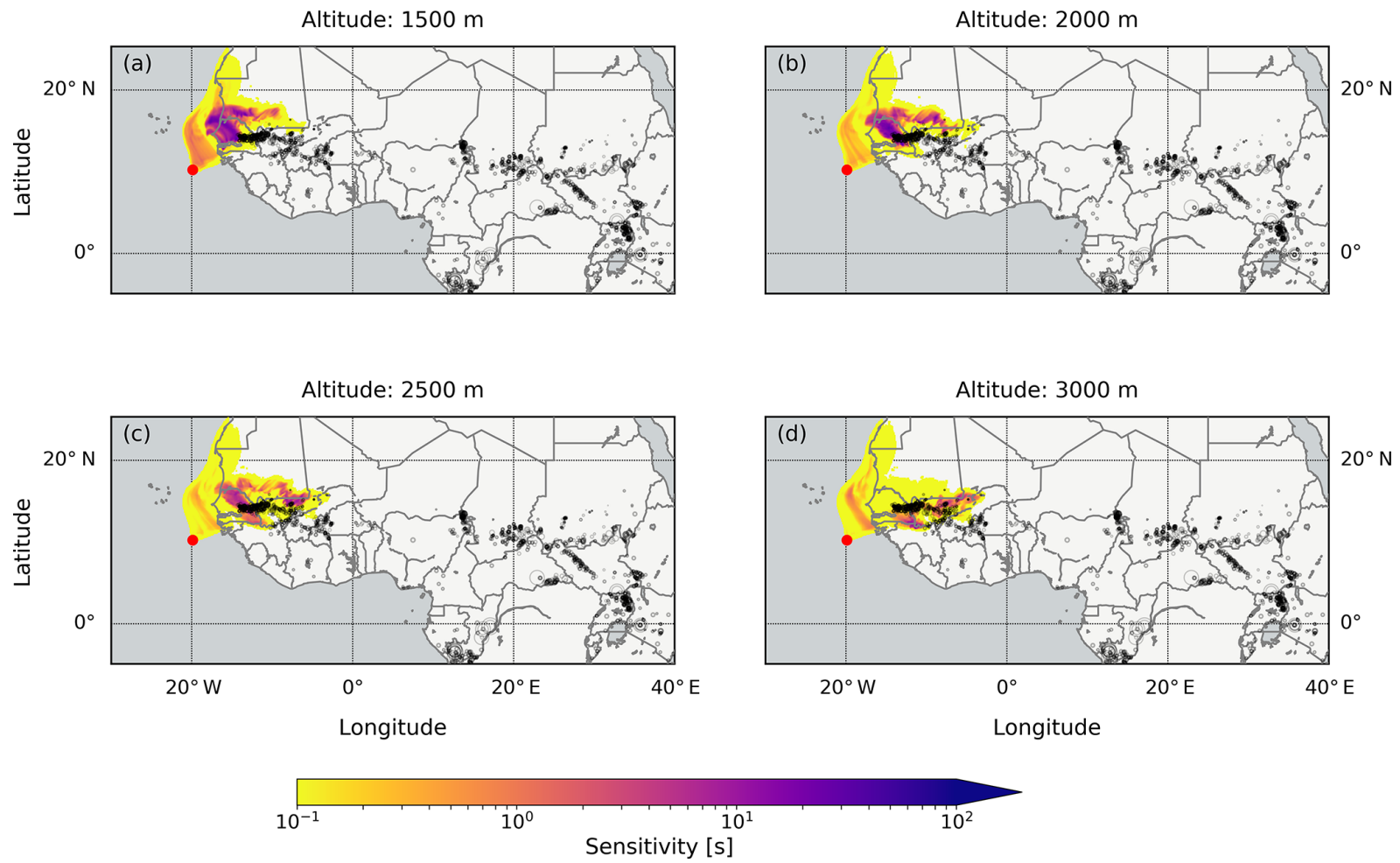

Figure 15. The emission sensitivity response function to the lowest $500 \mathrm{~m}$ layer for air parcels arriving at the receptor position in different altitudes above the RV Maria S. Merian on 13 October 2016 at midday, indicated by red dots (compare Figs. 9 and 11). The emission sensitivities were integrated over $2 \mathrm{~d}$ backwards. The black circles are fires which were detected between 10 and 12 October taken from the FINN database (Sect. 3.6). The circles are scaled with the calculated $\mathrm{CO}_{2}$ emissions.

source for VOCs. The simulated particles reach the measurement location over the open ocean at altitudes above 1500 up to $3000 \mathrm{~m}$ after $2 \mathrm{~d}$ (Fig. 15) or longer (not shown), depending on the source region. Thus, the measured VOC enhancements are probably caused by export of precursor molecules from the African continent due to the short lifetime of $\mathrm{HCHO}$ and $\mathrm{CHOCHO}$.

The results are different for 14 October when the measurements also show enhanced $\mathrm{HCHO}$ and $\mathrm{CHOCHO}$ values. The emission sensitivity response function is generally low for the lowest $1000 \mathrm{~m}$ (Fig. 16; similar results were also found for the lowest $500 \mathrm{~m}$, not shown). Only air older than $2 \mathrm{~d}$ (not shown) might originate from the continent, but also $4 \mathrm{~d}$ old air has only a small sensitivity to the continent (Fig. 16). The highest emission sensitivity to the lowest $1000 \mathrm{~m}$ is found above the open ocean south of the vessel's position. Furthermore, fires are unlikely to be important for the observed enhanced $\mathrm{HCHO}$ and $\mathrm{CHOCHO}$ values, as only a few small fires were detected in the potential continental source regions. Additionally, the source altitude is less clear due to similar emission sensitivities for different altitudes. The detected $\mathrm{HCHO}$ and $\mathrm{CHOCHO}$ might be located at an altitude between 1000 and $5000 \mathrm{~m}$.

For the HCHO enhancements observed on 17 October, the simulated emission sensitivities indicate air masses originat- ing from southerly central Africa (Angola, Democratic Republic of the Congo, Republic of the Congo, Gabon, and Republic of Equatorial Guinea; Fig. 17). The simulated air masses from the African continent reach the positions above the ship after $4 \mathrm{~d}$ at an altitude between 2000 and $4500 \mathrm{~m}$, consistent with MOZART-4 model simulations (Fig. 13). In the possible source regions, mostly different types of forests and grasslands were found (Mayaux et al., 2004), as well as fires with large emissions (Fig. 17). Both can emit precursors of HCHO. However, most fires are detected south of the possible source regions.

\section{Comparison with previous studies}

Several earlier studies showed that continental pollution can be transported over the open Atlantic Ocean, but none report similar transport for VOCs. Anderson et al. (1996) found outflow from the African continent in the Southern Hemisphere. They analysed measurements from a flight campaign in September/October 1992 in the south Atlantic Ocean and found enhanced aerosol number densities at 3000 to $4000 \mathrm{~m}$ with small loss of aerosol during the transport. However, their observations were mostly closer to the continent (distance between flight track and continent: $\sim 450-1500 \mathrm{~km}$, 

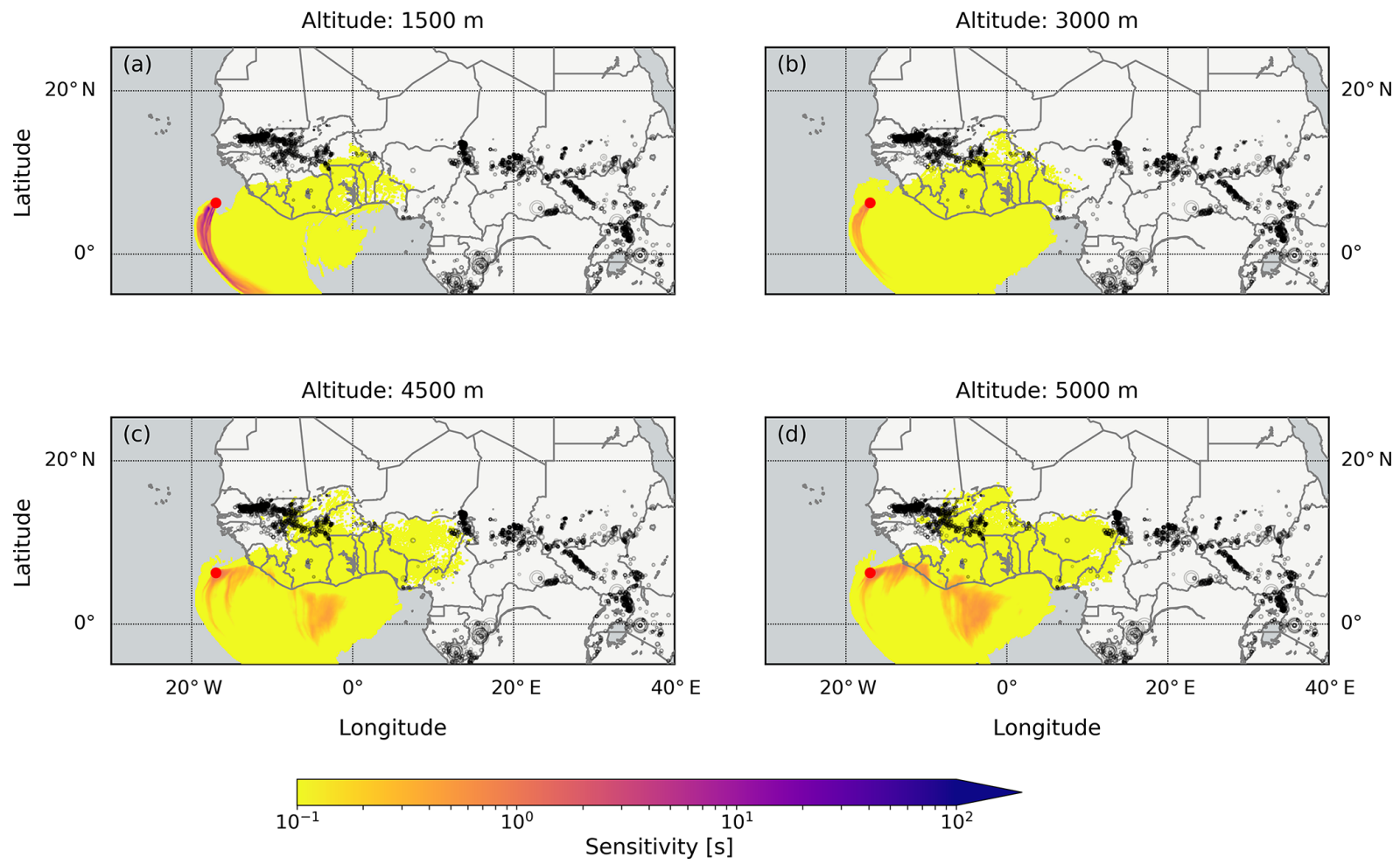

Figure 16. The emission sensitivity response function to the lowest $1000 \mathrm{~m}$ layer for air parcels arriving at the receptor position in different altitudes above the RV Maria S. Merian on 14 October 2016 at midday, indicated by red dots (compare Figs. 9 and 11). The emission sensitivities were integrated over $4 \mathrm{~d}$ backwards. The black circles are fires which were detected between 8 and 13 October taken from the FINN database (Sect. 3.6). The circles are scaled with the calculated $\mathrm{CO}_{2}$ emissions. Only certain altitudes are shown as altitudes of 2000 , 2500,3500 , and $4000 \mathrm{~m}$ have a similar emission sensitivity pattern to altitudes of 1500 and $3000 \mathrm{~m}$.

with one flight up to $3000 \mathrm{~km}$ ) than the cruise track of MSM58/2, with large distances between the potential continental source and the area of the measurements (13 October 2016: 950 km; 14 October 2016: $~ 660 \mathrm{~km}$; between cruise track and continent, 17 October 2016: $\sim 2700 \mathrm{~km}$ ). Chatfield et al. (1998) showed export of CO in their model study, which was done for the same campaign.

While VOCs have not been reported over the Atlantic Ocean in connection to pollution outflow events until now, both $\mathrm{HCHO}$ and $\mathrm{CHOCHO}$ have been observed over the open ocean before. So far to our knowledge, there have been no reports on MAX-DOAS measurements of $\mathrm{HCHO}$ over the Atlantic Ocean. However, Weller et al. (2000) measured in situ HCHO concentrations in the Atlantic boundary layer during the Albatross campaign (October/November 1996). They found enhanced values in tropical latitudes, attributing them to secondary production in absence of any local sources, ruling out pollution transport due to the short lifetime of HCHO. Furthermore, Notholt et al. (2000) performed absorption measurements by Fourier transform infrared (FTIR) spectroscopy on the same cruise as Weller et al. (2000) to analyse i.a. HCHO. They found a similar latitudinal dependency as Weller et al. (2000) and converted their own measurements as well as the measurements performed by
Weller et al. (2000) into total columns (assumed layer thickness: $0-9 \mathrm{~km}$ ). The retrieved columns are on the order of approximately $1.5 \times 10^{16}$ molec $\mathrm{cm}^{-2}$ between $10^{\circ} \mathrm{N}$ and the Equator, which agrees quite well with our MAX-DOAS measurements presented before. Also, south of the Equator, they found values on the order of $1.0 \times 10^{16}$ molec $\mathrm{cm}^{-2}$ with a further decrease towards the midlatitudes. Generally, their results agree in magnitude and latitudinal distribution with our results. Nevertheless, there are slight differences compared to the previous findings, since the scan angle dependency of the enhanced HCHO dSCD on 13, 14, and 17 October clearly indicate an elevated layer of $\mathrm{HCHO}$ enhancements which was not shown in the two studies (most likely due to the different measurement techniques). Because of the good agreement between the measurements of Notholt et al. (2000) and our measurements, this might indicate that the model data and the satellite measurements underestimate the amount of $\mathrm{HCHO}$ south of the Equator (Fig. 10).

Even though, in light of its short lifetime and missing sources over the open ocean, these enhanced levels of HCHO are surprising, several previous studies already have reported similar findings based on in satellite measurements (Wittrock et al., 2006; De Smedt et al., 2008; Meyer-Arnek et al., 2005). Meyer-Arnek et al. (2005), e.g. explained enhanced 

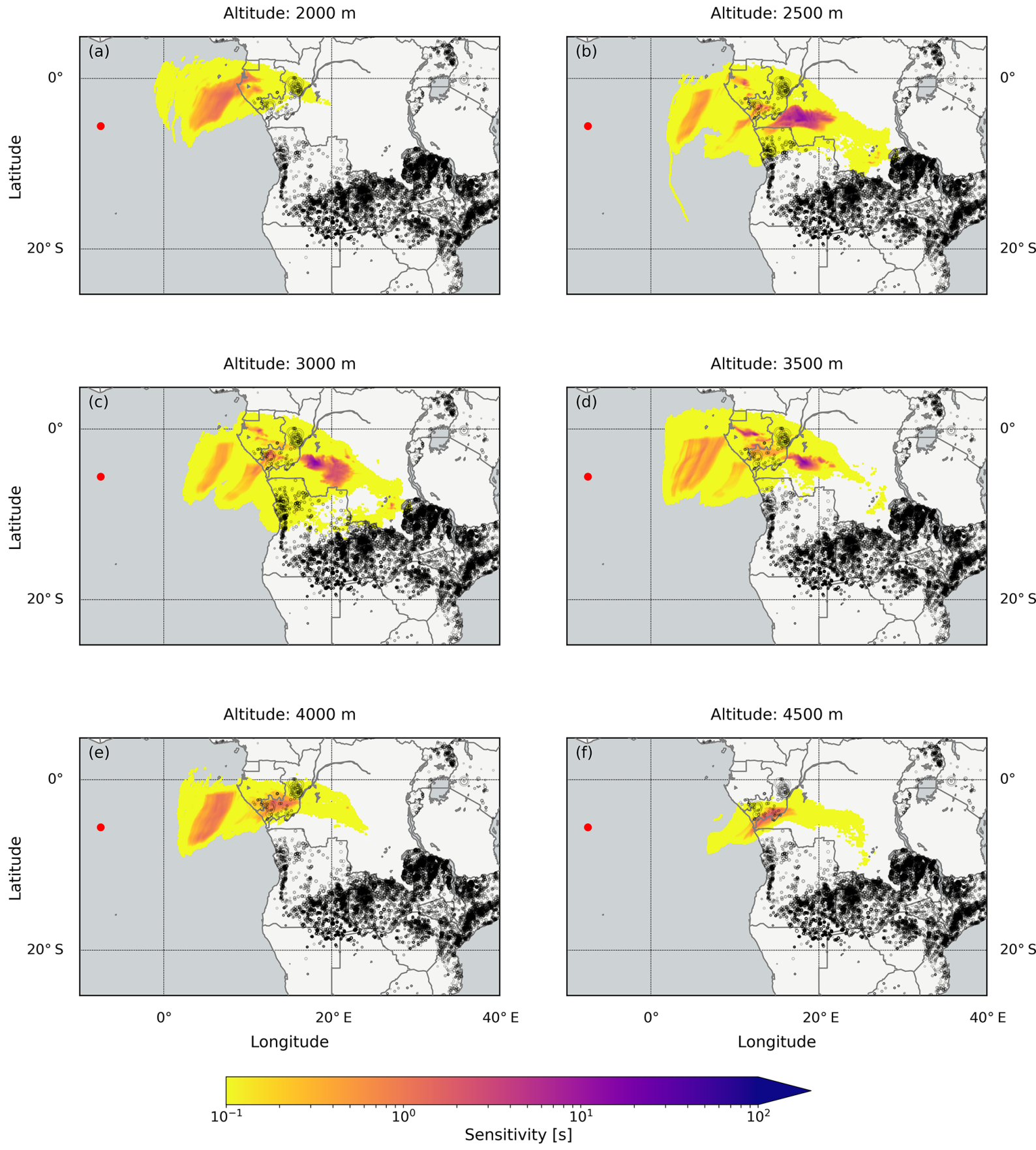

Figure 17. The emission sensitivity response function to the lowest $500 \mathrm{~m}$ layer for air parcels arriving at the receptor position in different altitudes above the RV Maria S. Merian on 17 October 2016 at midday, indicated by red dots (compare Fig. 9). The emission sensitivities were integrated over $4 \mathrm{~d}$ backwards. The black circles are fires which were detected between 12 and 14 October taken from the FINN database (Sect. 3.6). The circles are scaled with the calculated $\mathrm{CO}_{2}$ emissions.

HCHO values over the tropical Atlantic Ocean by transport and transformation of VOC emissions. Furthermore, they could show that biomass burning and biogenic emissions produce similar amounts of $\mathrm{HCHO}$, but that the transport of HCHO from biogenic emissions is in lower altitudes and usually stays closer to the source regions. Figures $15-17$ show detected fires in October 2016 for Africa south of the Equator and also some fires for Africa north of the Equator in the potential source regions. On 13 October, fires are clearly visible in the potential source region. Thus, the results from Meyer-Arnek et al. (2005) support our present results, which were collected far away from the coast and indicate that the 
observed $\mathrm{HCHO}$ enhancements might be caused by biomass burning emissions of $\mathrm{HCHO}$ precursors. In contrast, on 14 and 17 October, the number of fires is limited, and therefore biogenic origins might be more plausible sources for these regions. However, larger $\mathrm{NO}_{2}$ columns from biomass burning were not detected, which could be related to the short lifetime of $\mathrm{NO}_{2}$.

Also, over the Pacific Ocean, enhanced HCHO columns were observed by Peters et al. (2012) and Tan et al. (2018). In both studies, $\mathrm{HCHO}$ was detected in elevated layers of 400 and $500 \mathrm{~m}$, which is lower than the detected altitudes in this study. Therefore, they concluded that the increased values are related to precursors of $\mathrm{HCHO}$.

For $\mathrm{CHOCHO}$, there have been MAX-DOAS measurements over the Atlantic during two cruises with RV Polarstern in 2009 and 2011 (Mahajan et al., 2014). These campaigns showed complex results: while in 2009 (when the cruise track was slightly more west compared to our observations here), no CHOCHO enhancements could be observed, the 2011 cruise, which followed a path very similar to the present study, showed clear CHOCHO dSCD enhancements of about $1 \times 10^{15}$ molec $\mathrm{cm}^{-2}$ at around $5^{\circ} \mathrm{N}$. In those data, no clear scan angle dependency could be identified, so the vertical location of the observed CHOCHO masses remains unclear. Our present results are consistent with these previous findings, showing slightly smaller $\mathrm{CHOCHO}$ dSCDs in the same area in an elevated layer. On the other hand, Sinreich et al. (2010) investigated CHOCHO over the Pacific Ocean, up to $3000 \mathrm{~km}$ away from continental land sources. They found strongly enhanced dSCDs of approximately $3 \times 10^{15} \mathrm{molec} \mathrm{cm}^{-2}$ in the lowest elevation angles. Since their results show a clear scan angle dependency, Sinreich et al. (2010) concluded that CHOCHO was located in the marine boundary layer, pointing towards local production. On some days (for example, 17 or 21 October 2016), the same scan angle dependency above the detection limit is found in our measurements during COPMAR, which suggests that besides $\mathrm{CHOCHO}$ in elevated layers also some $\mathrm{CHOCHO}$ was located close to the ground.

Similarly to $\mathrm{HCHO}$, also $\mathrm{CHOCHO}$ has been reported to be present at enhanced levels over remote ocean regions in satellite observations (Vrekoussis et al., 2009; Stavrakou et al., 2009; Lerot et al., 2010). These CHOCHO enhancements are mostly visible in regions of strong biogenic activity and biomass burning, and are usually attributed to local production from $\mathrm{CHOCHO}$ precursors either originating from marine biota or from transported organic aerosol rich in dissolved organic carbon (Vrekoussis et al., 2009).

Our MAX-DOAS measurements suggest that the observed $\mathrm{HCHO}$ and $\mathrm{CHOCHO}$ enhancement is partly located in an elevated atmospheric layer which is in contrast to previous publications. It seems more likely that on the days where our measurements show enhanced values their source is related to transported precursors, which is also in line with the findings presented in Sect. 4.4. Possibly, the aerosols trap the gases which are lifted and transported together. These stored gases can then be re-released to the gas phase by reversible desorption after several days. Similar results were found for a case study over continental area in Asia by Alvarado (2016). The presence of a combination of dust and biogenic aerosol, and thus potential VOC sources in that region and during that season, could be shown by Ridley et al. (2012) using Cloud-Aerosol Lidar and Infrared Pathfinder Satellite Observations (CALIOP) and model data. Furthermore, Volkamer et al. (2015) found similar results for the Pacific Ocean. They found in the equatorial Pacific west of the American continent enhanced $\mathrm{CHOCHO}$ columns mostly in elevated layers, ruling out marine sources.

\section{Summary and conclusions}

During the Continental Outflow of Pollutants towards the MArine tRoposphere (COPMAR) project, a Multi-AXis Differential Absorption Spectrometer (MAX-DOAS) was operated aboard RV Maria S. Merian for cruise MSM58/2, which was conducted from Ponta Delgada (Azores) to Cape Town (South Africa) in October 2016. The goal of the project was to investigate the enhanced quantities of formaldehyde (HCHO) and glyoxal (CHOCHO) frequently observed over the remote Atlantic Ocean in satellite measurements and model simulations.

We analysed our measurements for the latitudinal and diurnal variation of stratospheric $\mathrm{NO}_{2}$, which are in good agreement with previous studies (e.g. Peters et al., 2012; Kreher et al., 1995), showing proper operation of the instrument. This gives us confidence in the enhanced HCHO and $\mathrm{CHOCHO}$ columns observed in an elevated layer during the cruise in the area of expected outflow.

The MAX-DOAS observations of $\mathrm{HCHO}$ and $\mathrm{CHOCHO}$ show good or moderate agreement with satellite data and model simulations, with correlation coefficients of 0.72 (HCHO) and 0.55 (CHOCHO) between MAX-DOAS and MOZART-4 and between MAX-DOAS and satellite observations of 0.79 (OMI) and 0.72 (GOME-2B) for $\mathrm{HCHO}$ and 0.56 (OMI) for CHOCHO. MAX-DOAS HCHO were often higher than suggested by both satellite and model data. In contrast, CHOCHO MAX-DOAS observations are often lower than the model and satellite data. The enhanced HCHO levels which are observed in the Southern Hemisphere are not present in satellite and model data. This might be related to the fact that the latter two datasets are monthly means and the outflow event of an individual day cannot be resolved in these datasets.

For $\mathrm{HCHO}$ on $3 \mathrm{~d}$ and for $\mathrm{CHOCHO}$ on $2 \mathrm{~d}$, our measurements show clearly enhanced levels of these trace gases. The dependency of the measured dSCD on elevation angle suggests the presence of $\mathrm{HCHO}$ (on 13, 14, and 17 October) and $\mathrm{CHOCHO}$ (on 13 and 14 October only) in elevated atmospheric layers, most likely above the marine boundary 
layer. On 13 and 17 October, this clearly points to $\mathrm{HCHO}$, $\mathrm{CHOCHO}$, and/or their precursors being transported over long distances from the African continent. FLEXPART emission sensitivities for the ship's position from potential source regions show the presence of air masses originating from the African continent in altitudes between 1500 and $3000 \mathrm{~m}$, as well as between 2000 and $4500 \mathrm{~m}$ in the Northern Hemisphere and Southern Hemisphere, respectively. This is in agreement with our observations. These air masses reach the measurement location over the Atlantic Ocean after 2 and $4 \mathrm{~d}$. On 14 October, the results are less clear. Here, the emission sensitivity to the continent is small, whereas the emission sensitivity is high to the open ocean. The air from the continent reaches the vessel's position after approximately $4 \mathrm{~d}$ at an altitude between 1000 and $5000 \mathrm{~m}$. MOZART-4 simulations show enhancements of both trace gases at an altitude of $3000-6000 \mathrm{~m}$ and $3000-4000 \mathrm{~m}$ in the Northern Hemisphere and Southern Hemisphere, respectively, which confirms our findings, although the MOZART-4 altitudes are slightly higher in the Northern Hemisphere. These results are in general good agreement with previous studies of trace gases transported from Africa over the Atlantic Ocean.

Although our measurements do not show large levels of $\mathrm{NO}_{2}$, these $\mathrm{VOC}$ enhancements probably originate from biomass burning on 13 October, as the source regions agree with fire detections from the FINN dataset. In contrast, for 17 October, only a small number of fires were observed in the potential source region, and therefore biogenic origin might be the more realistic source. Thus, the main source of the detected VOC outflow is probably related to vegetation and/or biomass burning on the African continent.

The observed aerosol differs between Africa north and south of the Equator (having a different AOD and Ångström exponent), and therefore the outflow in both hemispheres seems to be from different sources. While the aerosol observed in the Northern Hemisphere shows clear characteristics of desert dust, the aerosol measurements on 17 October (the day with enhanced $\mathrm{HCHO}$ values in elevated layers in the Southern Hemisphere) hint towards continental aerosol.

The present study is the first to confirm the enhanced levels of $\mathrm{HCHO}$ and $\mathrm{CHOCHO}$ frequently observed from satellites over the Atlantic Ocean using ship-based measurements. Our findings suggest that these enhanced levels of HCHO and $\mathrm{CHOCHO}$ are present in elevated atmospheric layers in the free troposphere, implying that these VOCs or their precursors are transported from the African continent or that we have re-released gases from a gas-aerosol combination. Further measurement campaigns should be conducted to investigate this pollution export in more detail, in order to shed light on the chemical transformations occurring in these plumes and thus enabling an explanation of the presence of shortlived species so far from their emission sources.
Data availability. The common cross sections used in this study are available from the cited references.

The GOME-2 spectra (lv1b) and the OMI spectra (lv1) were provided by EUMETSAT and NASA and are available at https://www.eumetsat.int/website/home/Data/Products/ Level1Data/index.html (last access: 28 June 2018) and https://disc.gsfc.nasa.gov/datasets?page $=1 \&$ source=AURAOMI (last access: 28 June 2018), respectively.

The lv2 and lv3 satellite data are available from the authors upon request.

The MAX-DOAS data will be published on PANGAEA.

The MOZART-4 global model output is available at http://www. acom.ucar.edu/wrf-chem/mozart.shtml (last access: 17 April 2018).

NASA's AERONET data is accessible via https://aeronet. gsfc.nasa.gov/new_web/maritime_aerosol_network.html (last access: 5 March 2018).

Author contributions. LKB collected the data during ship cruise MSM58/2, analysed the data, and combined the datasets. AH, AR, and EP provided additional feedback on the manuscript. AR contributed the GOME-2A and GOME-2B NO 2 satellite data. EP designed the instrument and provided the programme for the correction of the ship's movement. LMAA contributed the GOME-2B and OMI satellite data of $\mathrm{HCHO}$ and $\mathrm{CHOCHO}$. ABKH and $\mathrm{AH}$ ran the FLEXPART simulations. MV conceived the COPMAR campaign. All co-authors contributed to the data interpretation and the manuscript preparation.

Competing interests. The authors declare that they have no conflict of interest.

Acknowledgements. This study has been funded by the University of Bremen, the state of Bremen, and by the DFG-Research Center/Cluster of Excellence "The Ocean in the Earth System". We further thank the "DFG Senatskommission für Ozeanographie" for the travelling time on RV Maria S. Merian and the "Leitstelle Deutsche Forschungsschiffe" for the logistical support. We acknowledge use of MOZART-4 global model output (available at http://www.acom.ucar.edu/wrf-chem/mozart.shtml, last access: 17 April 2018). GOME-2 lv1b radiances have been provided by EUMETSAT and OMI lv1 data have been provided by NASA. Furthermore, we acknowledge the MAN effort of NASA's AERONET group led by Alexander Smirnov by providing a calibrated instrument and by maintaining the MAN database. Anna Beata Kalisz Hedegaard's PhD work is financed through a DLR-DAAD Research Fellowship. All FLEXPART computations were performed at the "Aether" HPC cluster at the University of Bremen, funded by DFG within the scope of the Excellence Initiative.

Financial support. The article processing charges for this openaccess publication were covered by the University of Bremen.

Review statement. This paper was edited by Steven Brown and reviewed by two anonymous referees. 


\section{References}

Aliwell, S. R., Van Roozendael, M., Johnston, P. V., Richter, A., Wagner, T., Arlander, D. W., Burrows, J. P., Fish, D. J., Jones, R. L., Tømkvist, K. K., Lambert, J. C., Pfeilsticker, K., and Pundt, I.: Analysis for BrO in zenith-sky spectra: An intercomparison exercise for analysis improvement, J. Geophys. Res.-Atmos., 107, 4199, https://doi.org/10.1029/2001JD000329, 2002

Alvarado, L. M. A.: Investigating the role of glyoxal using satellite and MAX-DOAS measurements, $\mathrm{PhD}$ thesis, University of Bremen, 2016.

Alvarado, L. M. A., Richter, A., Vrekoussis, M., Wittrock, F., Hilboll, A., Schreier, S. F., and Burrows, J. P.: An improved glyoxal retrieval from OMI measurements, Atmos. Meas. Tech., 7, 4133-4150, https://doi.org/10.5194/amt-7-4133-2014, 2014.

Alvarado, L. M. A., Richter, A., Hilboll, A., Vrekoussis, M., Burrows, J. P., Daskalakis, N., Myriokefalitakis, S., and Kanakidou, M.: Uniform formaldehyde retrieval applied to SCIAMACHY, OMI, and GOME-2 (A and B) data from 2003 to 2016, Geophys. Res. Abstr., EGU2018-14907, 2018.

Alvarado, L. M. A., Richter, A., Hilboll, A., Vrekoussis, M., Myriokefalitakis, S., Kanakidou, M., and Burrows, J. P.: An improved and homogenized formaldehyde and glyoxal retrieval from multiples satellite instruments, in preparation, 2019.

Anderson, B. E., Grant, W. B., Gregory, G. L., Browell, E. V., Collins, J. E., Sachse, G. W., Bagwell, D. R., Hudgins, C. H., Blake, D. R., and Blake, N. J.: Aerosols from biomass burning over the tropical South Atlantic region: Distributions and impacts, J. Geophys. Res.-Atmos., 101, 24117-24137, https://doi.org/10.1029/96JD00717, 1996.

Arlander, D. W., Brüning, D., Schmidt, U., and Ehhalt, D. H.: The tropospheric distribution of formaldehyde during TROPOZ II, J. Atmos. Chem., 22, 251-269, https://doi.org/10.1007/BF00696637, 1995.

Behrens, L. K.: Track of Maria S. Merian cruise MSM58/2 from 2016-10-08 to 2016-10-25, Ponta Delgada to Cape Town, PANGAEA, https://doi.org/10.1594/PANGAEA.869353, 2016.

Boersma, K. F., Eskes, H. J., and Brinksma, E.: Error analysis for tropospheric NO2 retrieval from space, J. Geophys. Res., 109, D04311, https://doi.org/10.1029/2003JD003962, 2004.

Boersma, K. F., Jacob, D. J., Eskes, H. J., Pinder, R. W., Wang, J., and van der A, R. J.: Intercomparison of SCIAMACHY and OMI tropospheric $\mathrm{NO}_{2}$ columns: Observing the diurnal evolution of chemistry and emissions from space, J. Geophys. Res.-Atmos., 113, D16S26, https://doi.org/10.1029/2007JD008816, 2008.

Bogumil, K., Orphal, J., Homann, T., Voigt, S., Spietz, P., Fleischmann, O. C., Vogel, A., Hartmann, M., Kromminga, H., Bovensmann, H., Frerick, J., and Burrows, J. P.: Measurements of molecular absorption spectra with the SCIAMACHY preflight model: Instrument characterization and reference data for atmospheric remote-sensing in the $230-2380 \mathrm{~nm}$ region, J. Photoch. Photobio. A, 157, 167-184, https://doi.org/10.1016/S10106030(03)00062-5, 2003.

Burkert, J., Andres-Hernandez, M.-D., Stöbener, D., Burrows, J. P., Weissenmayer, M., and Kraus, A.: Peroxy radical and related trace gas measurements in the boundary layer above the Atlantic Ocean, J. Geophys. Res., 106, 5457-5477, https://doi.org/10.1029/2000JD900613, 2001.
Burrows, J. P., Platt, U., and Borrell, P. (Eds.): The Remote Sensing of Tropospheric Composition from Space, Physics of Earth and Space Environments, Springer-Verlag, Berlin Heidelberg, https://doi.org/10.1007/978-3-642-14791-3, 2011.

Callies, J., Corpaccioli, E., Eisinger, M., Hahne, A., and Lefebvre, A.: GOME-2 - Metop's second-generation sensor for operational ozone monitoring, ESA Bull.-Eur. Space, 102, 28-36, 2000.

Chatfield, R. B., Vastano, J. A., Li, L., Sachse, G. W., and Connors, V. S.: The Great African Plume from biomass burning: Generalizations from a three-dimensional study of TRACE A carbon monoxide, J. Geophys. Res., 103, 28059-28077, https://doi.org/10.1029/97JD03363, 1998.

Chung, S. H. and Seinfeld, J. H.: Global distribution and climate forcing of carbonaceous aerosols, J. Geophys. Res.-Atmos., 107, 4407, https://doi.org/10.1029/2001JD001397, 2002.

De Smedt, I., Müller, J.-F., Stavrakou, T., van der A, R., Eskes, H., and Van Roozendael, M.: Twelve years of global observations of formaldehyde in the troposphere using GOME and SCIAMACHY sensors, Atmos. Chem. Phys., 8, 4947-4963, https://doi.org/10.5194/acp-8-4947-2008, 2008.

Dikty, S. and Richter, A.: GOME-2 on MetOp-A Support for Analysis of GOME-2 In-Orbit Degradation and Impacts on Level 2 Data Products Final Report, Tech. rep., University of Bremen, Institut of Remote Sensing, available at: http://www.iup.uni-bremen.de/doas/reports/Final Report_Level-2_Data_GOME-2_Degradation.pdf (last access: 9 October 2018), 2011.

Emmons, L. K., Walters, S., Hess, P. G., Lamarque, J.-F., Pfister, G. G., Fillmore, D., Granier, C., Guenther, A., Kinnison, D., Laepple, T., Orlando, J., Tie, X., Tyndall, G., Wiedinmyer, C., Baughcum, S. L., and Kloster, S.: Description and evaluation of the Model for Ozone and Related chemical Tracers, version 4 (MOZART-4), Geosci. Model Dev., 3, 43-67, https://doi.org/10.5194/gmd-3-43-2010, 2010.

Fairlie, T. D., Jacob, D. J., and Park, R. J.: The impact of transpacific transport of mineral dust in the United States, Atmos. Environ. 41, 1251-1266, https://doi.org/10.1016/j.atmosenv.2006.09.048, 2007.

Fleischmann, O. C., Hartmann, M., Burrows, J. P., and Orphal, J.: New ultraviolet absorption cross-sections of $\mathrm{BrO}$ at atmospheric temperatures measured by time-windowing Fourier transform spectroscopy, J. Photochem. Photobiol. A, 168, 117132, https://doi.org/10.1016/j.jphotochem.2004.03.026, 2004.

Fu, T. M., Jacob, D. J., Wittrock, F., Burrows, J. P., Vrekoussis, M., and Henze, D. K.: Global budgets of atmospheric glyoxal and methylglyoxal, and implications for formation of secondary organic aerosols, J. Geophys. Res.-Atmos., 113, D15303, https://doi.org/10.1029/2007JD009505, 2008

Generoso, S., Bey, I., Labonne, M., and Bréon, F. M.: Aerosol vertical distribution in dust outflow over the Atlantic: Comparisons between GEOS-Chem and Cloud-Aerosol Lidar and Infrared Pathfinder Satellite Observation (CALIPSO), J. Geophys. Res.Atmos., 113, D24209, https://doi.org/10.1029/2008JD010154, 2008.

Gil, M., Yela, M., Gunn, L. N., Richter, A., Alonso, I., Chipperfield, M. P., Cuevas, E., Iglesias, J., Navarro, M., Puentedura, O., and Rodríguez, S.: $\mathrm{NO}_{2}$ climatology in the northern subtropical region: diurnal, seasonal and interannual variability, Atmos. 
Chem. Phys., 8, 1635-1648, https://doi.org/10.5194/acp-8-16352008, 2008.

Gorshelev, V., Serdyuchenko, A., Weber, M., Chehade, W., and Burrows, J. P.: High spectral resolution ozone absorption crosssections - Part 1: Measurements, data analysis and comparison with previous measurements around $293 \mathrm{~K}$, Atmos. Meas. Tech., 7, 609-624, https://doi.org/10.5194/amt-7-609-2014, 2014.

Heckel, A., Richter, A., Tarsu, T., Wittrock, F., Hak, C., Pundt, I., Junkermann, W., and Burrows, J. P.: MAX-DOAS measurements of formaldehyde in the Po-Valley, Atmos. Chem. Phys., 5, 909918, https://doi.org/10.5194/acp-5-909-2005, 2005.

Holben, B., Eck, T., Slutsker, I., Tanré, D., Buis, J., Setzer, A., Vermote, E., Reagan, J., Kaufman, Y. J., Nakajima, T., Lavenu, F., Jankowiak, I., and Smirnov, A.: AERONET-A Federated Instrument Network and Data Archive for Aerosol Characterization, Remote Sens. Environ., 66, 1-16, https://doi.org/10.1016/S0034-4257(98)00031-5, 1998.

Ichoku, C., Levy, R., Kaufman, Y. J., Remer, L. A., Li, R.-R., Martins, V. J., Holben, B. N., Abuhassan, N., Slutsker, I., Eck, T. F., and Pietras, C.: Analysis of the performance characteristics of the five-channel Microtops II Sun photometer for measuring aerosol optical thickness and precipitable water vapor, J. Geophys. Res., 107, 4179, https://doi.org/10.1029/2001JD001302, 2002.

Ichoku, C., Kaufman, Y. J., Remer, L. A., and Levy, R.: Global aerosol remote sensing from MODIS, Adv. Space Res., 34, 820827, https://doi.org/10.1016/j.asr.2003.07.071, 2004.

Irie, H., Takashima, H., Kanaya, Y., Boersma, K. F., Gast, L., Wittrock, F., Brunner, D., Zhou, Y., and Van Roozendael, M.: Eight-component retrievals from ground-based MAXDOAS observations, Atmos. Meas. Tech., 4, 1027-1044, https://doi.org/10.5194/amt-4-1027-2011, 2011.

Knobelspiesse, K. D., Pietras, C., and Fargion, G. S.: SunPointing-Error Correction for Sea Deployment of the MICROTOPS II Handheld Sun Photometer, J. Atmos. Ocean. Tech., 20, 767-771, https://doi.org/10.1175/15200426(2003)20<767:SPECFS>2.0.CO;2, 2003.

Knobelspiesse, K. D., Pietras, C., Fargion, G. S., Wang, M., Frouin, R., Miller, M. A., Subramaniam, A., and Balch, W. M.: Maritime aerosol optical thickness measured by handheld sun photometers, Remote Sens. Environ., 93, 87-106, https://doi.org/10.1016/j.rse.2004.06.018, 2004.

Koppmann, R. (Ed.): Volatile Organic Compounds in the Atmosphere, Blackwell Publishing Ltd, 2007.

Kreher, K., Fiedler, M., Gomer, T., Stutz, J., and Platt, U.: The latitudinal distribution $\left(50^{\circ} \mathrm{N}-50^{\circ} \mathrm{S}\right)$ of $\mathrm{NO}_{2}$ and $\mathrm{O}_{3}$ in October/November 1990, Geophys. Res. Lett., 22, 1217-1220, https://doi.org/10.1029/95GL01113,1995.

Lee, D. S., Köhler, I., Grobler, E., Rohrer, F., Sausen, R., GallardoKlenner, L., Olivier, J. G. J., Dentener, F. J., and Bouwman, A. F.: Estimations of global $\mathrm{NO}_{x}$ emissions and their uncertainties, Atmos. Environ., 31, 1735-1749, https://doi.org/10.1016/S13522310(96)00327-5, 1997.

Lerot, C., Stavrakou, T., De Smedt, I., Müller, J.-F., and Van Roozendael, M.: Glyoxal vertical columns from GOME2 backscattered light measurements and comparisons with a global model, Atmos. Chem. Phys., 10, 12059-12072, https://doi.org/10.5194/acp-10-12059-2010, 2010.
Levelt, P. F., Hilsenrath, E., Leppelmeier, G. W., Oord, G. H. J. V. D., Bhartia, P. K., Tamminen, J., Haan, J. F. D., and Veefkind, J. P.: Scince Objectives of the Ozone Monitoring Instrument, IEEE T. Geosci. Remote, 44, 1199-1208, https://doi.org/10.1109/TGRS.2006.872333, 2006.

Lorente, A., Folkert Boersma, K., Yu, H., Dörner, S., Hilboll, A., Richter, A., Liu, M., Lamsal, L. N., Barkley, M., De Smedt, I., Van Roozendael, M., Wang, Y., Wagner, T., Beirle, S., Lin, J.T., Krotkov, N., Stammes, P., Wang, P., Eskes, H. J., and Krol, M.: Structural uncertainty in air mass factor calculation for $\mathrm{NO} 2$ and HCHO satellite retrievals, Atmos. Meas. Tech., 10, 759-782, https://doi.org/10.5194/amt-10-759-2017, 2017.

Mahajan, A. S., Prados-Roman, C., Hay, T. D., Lampel, J., Pöhler, D., Großmann, K., Tschritter, J., Frieß, U., Platt, U., Johnston, P., Kreher, K., Wittrock, F., Burrows, J. P., Plane, J. M., and Saiz-Lopez, A.: Glyoxal observations in the global marine boundary layer, J. Geophys. Res.-Atmos., 119, 6160-6169, https://doi.org/10.1002/2013JD021388, 2014.

Mayaux, P., Bartholome, E., Fritz, S., and Belward, A.: A New Land Cover Map of Africa for the Year 2000, J. Biogeogr., 31, 861877, https://doi.org/10.1111/j.1365-2699.2004.01073.x, 2004.

Meller, R. and Moortgat, G. K.: Temperature dependence of the absorption cross sections of formaldehyde between 223 and $323 \mathrm{~K}$ in the wavelength range $225-375 \mathrm{~nm}$, J. Geophys. Res., 105, 7089-7101, https://doi.org/10.1029/1999JD901074, 2000.

Meyer-Arnek, J., Ladstätter-Weißenmayer, A., Richter, A., Wittrock, F., and Burrows, J. P.: A study of the trace gas columns of $\mathrm{O}_{3}, \mathrm{NO}_{2}$ and $\mathrm{HCHO}$ over Africa in September 1997, Faraday Discuss., 130, 387-405, https://doi.org/10.1039/b502106p, 2005.

Morys, M., Mims, F. M., Hagerup, S., Anderson, S. E., Baker, A., Kia, J., and Walkup, T.: Design, calibration, and performance of MICROTOPS II handheld ozone monitor and Sun photometer, J. Geophys. Res., 106, 14573-14582, https://doi.org/10.1029/2001JD900103, 2001.

Munro, R., Lang, R., Klaes, D., Poli, G., Retscher, C., Lindstrot, R., Huckle, R., Lacan, A., Grzegorski, M., Holdak, A., Kokhanovsky, A., Livschitz, J., and Eisinger, M.: The GOME2 instrument on the Metop series of satellites: instrument design, calibration, and level 1 data processing - an overview, Atmos. Meas. Tech., 9, 1279-1301, https://doi.org/10.5194/amt-9-12792016, 2016.

Myriokefalitakis, S., Vrekoussis, M., Tsigaridis, K., Wittrock, F., Richter, A., Brühl, C., Volkamer, R., Burrows, J. P., and Kanakidou, M.: The influence of natural and anthropogenic secondary sources on the glyoxal global distribution, Atmos. Chem. Phys., 8, 4965-4981, https://doi.org/10.5194/acp-8-4965-2008, 2008.

Notholt, J., Toon, G. C., Rinsland, C. P., Pougatchev, N. S., Jones, N. B., Connor, B. J., Weller, R., Gautrois, M., and Schrems, O.: Latitudinal variations of trace gas concentrations in the free troposphere measured by solar absorption spectroscopy during a ship cruise, J. Geophys. Res.-Atmos., 105, 1337-1349, https://doi.org/10.1029/1999JD900940, 2000.

Peters, E., Wittrock, F., Großmann, K., Frieß, U., Richter, A., and Burrows, J. P.: Formaldehyde and nitrogen dioxide over the remote western Pacific Ocean: SCIAMACHY and GOME-2 validation using ship-based MAX-DOAS observations, Atmos. Chem. Phys., 12, 11179-11197, https://doi.org/10.5194/acp-1211179-2012, 2012. 
Platt, U. and Stutz, J.: Differential Optical Absorption Spectroscopy, Physics of Earth and Space Environments, Springer Berlin, https://doi.org/10.1007/978-3-540-75776-4, 2008.

Platt, U., Marquard, L., Wagner, T., and Perner, D.: Corrections for zenith scattered light DOAS, Geophys. Res. Lett., 24, 17591762, https://doi.org/10.1029/97GL01693, 1997.

Polyansky, O. L., Kyuberis, A. A., Zobov, N. F., Tennyson, J., Yurchenko, S. N., and Lodi, L.: ExoMol molecular line lists XXX: a complete high-accuracy line list for water, Mon. Not. R. Astron. Soc., 480, 2597-2608, https://doi.org/10.1093/mnras/sty1877, 2018.

Porter, J. N., Miller, M., Pietras, C., and Motell, G.: Ship-Based Sun Photometer Measurements Using Microtops Sun Photometers, J. Atmos. Ocean. Tech., 18, 765-774, https://doi.org/10.1175/15200426(2001)018<0765:SBSPMU>2.0.CO;2, 2001.

Richter, A.: Absorptionsspektroskopische Messungen stratosphärischer Spurengase über Bremen, $53^{\circ} \mathrm{N}, \mathrm{PhD}$ thesis, University of Bremen, 1997.

Richter, A. and Burrows, J. P.: Tropospheric NO2 from GOME measurements, Adv. Space Res., 29, 1673-1683, https://doi.org/10.1016/S0273-1177(02)00100-X, 2002.

Richter, A., Begoin, M., Hilboll, A., and Burrows, J. P.: An improved $\mathrm{NO}_{2}$ retrieval for the GOME-2 satellite instrument, Atmos. Meas. Tech., 4, 1147-1159, https://doi.org/10.5194/amt-41147-2011, 2011.

Ridley, D. A., Heald, C. L., and Ford, B.: North African dust export and deposition: A satellite and model perspective, J. Geophys. Res.-Atmos., 117, D02202, https://doi.org/10.1029/2011JD016794, 2012.

Rothman, L. S., Gordon, I. E., Barber, R. J., Dothe, H., Gamache, R. R., Goldman, A., Perevalov, V. I., Tashkun, S. A., and Tennyson, J.: HITEMP, the high-temperature molecular spectroscopic database, J. Quant. Spectrosc. Ra., 111, 2139-2150, https://doi.org/10.1016/j.jqsrt.2010.05.001, 2010.

Rozanov, V., Rozanov, A., Kokhanovsky, A., and Burrows, J.: Radiative transfer through terrestrial atmosphere and ocean: Software package SCIATRAN, J. Quant. Spectrosc. Ra., 133, 13-71, https://doi.org/10.1016/j.jqsrt.2013.07.004, 2014.

Schepanski, K., Heinold, B., and Tegen, I.: Harmattan, Saharan heat low, and West African monsoon circulation: modulations on the Saharan dust outflow towards the North Atlantic, Atmos. Chem. Phys., 17, 10223-10243, https://doi.org/10.5194/acp-17-102232017, 2017.

Seibert, P. and Frank, A.: Source-receptor matrix calculation with a Lagrangian particle dispersion model in backward mode, Atmos. Chem. Phys., 4, 51-63, https://doi.org/10.5194/acp-4-512004, 2004.

Senne, T., Stutz, J., and Platt, U.: Measurements of the latitudinal distribution of $\mathrm{NO}_{2}$ column density and layer height in Oct./Nov. 1993, Geophys. Res. Lett., 23, 805-808, https://doi.org/10.1029/96GL00852, 1996.

Serdyuchenko, A., Gorshelev, V., Weber, M., Chehade, W., and Burrows, J. P.: High spectral resolution ozone absorption crosssections - Part 2: Temperature dependence, Atmos. Meas. Tech., 7, 625-636, https://doi.org/10.5194/amt-7-625-2014, 2014.

Singh, H., Chen, Y., Staudt, A., Jacob, D., Blake, D., Heikes, B., and Snow, J.: Evidence from the Pacific troposphere for large global sources of oxygenated organic compounds, Nature, 410 , 1078-1081, https://doi.org/10.1038/35074067, 2001.

Sinreich, R., Coburn, S., Dix, B., and Volkamer, R.: Ship-based detection of glyoxal over the remote tropical Pacific Ocean, Atmos. Chem. Phys., 10, 11359-11371, https://doi.org/10.5194/acp-1011359-2010, 2010.

Smirnov, A., Holben, B. N., Slutsker, I., Giles, D. M., McClain, C. R., Eck, T. F., Sakerin, S. M., Macke, A., Croot, P., Zibordi, G., Quinn, P. K., Sciare, J., Kinne, S., Harvcy, M., Smyth, T. J., Piketh, S., Zielinski, T., Proshutinsky, A., Goes, J. I., Nelson, N. B., Larouche, P., Radionov, V. F., Goloub, P., Krishna Moorthy, K., Matarrese, R., Robertson, E. J., and Jourdin, F.: Maritime Aerosol Network as a component of Aerosol Robotic Network, J. Geophys. Res.-Atmos., 114, D06204, https://doi.org/10.1029/2008JD011257, 2009.

Solomon, S., Russell, J. I., and Gordley, L.: Observations of the diurnal variation of nitrogen dioxide in the stratosphere, J. Geophys. Res., 91,5455-5464, https://doi.org/10.1029/JD091iD05p05455, 1986.

Stavrakou, T., Müller, J.-F., De Smedt, I., Van Roozendael, M., Kanakidou, M., Vrekoussis, M., Wittrock, F., Richter, A., and Burrows, J. P.: The continental source of glyoxal estimated by the synergistic use of spaceborne measurements and inverse modelling, Atmos. Chem. Phys., 9, 8431-8446, https://doi.org/10.5194/acp-9-8431-2009, 2009.

Stohl, A. and Thomson, D. J.: A density correction for lagrangian particle dispersion models, Bound.-Lay. Meteorol., 90, 155-167, https://doi.org/10.1023/A:1001741110696, 1999.

Stohl, A., Hittenberger, M., and Wotawa, G.: Validation of the lagrangian particle dispersion model flexpart against largescale tracer experiment data, Atmos. Environ., 32, 4245-4264, https://doi.org/10.1016/S1352-2310(98)00184-8, 1998.

Stohl, A., Forster, C., Frank, A., Seibert, P., and Wotawa, G.: Technical note: The Lagrangian particle dispersion model FLEXPART version 6.2, Atmos. Chem. Phys., 5, 2461-2474, https://doi.org/10.5194/acp-5-2461-2005, 2005.

Takashima, H., Irie, H., Kanaya, Y., and Syamsudin, F.: $\mathrm{NO}_{2}$ observations over the western Pacific and Indian Ocean by MAXDOAS on Kaiyo, a Japanese research vessel, Atmos. Meas. Tech., 5, 2351-2360, https://doi.org/10.5194/amt-5-2351-2012, 2012.

Takemura, T., Okamoto, H., Maruyama, Y., Numaguti, A., Higurashi, A., and Nakajima, T.: Global three-dimensional simulation of aerosol optical thickness distribution of various origins, J. Geophys. Res.-Atmos., 105, 17853-17873, https://doi.org/10.1029/2000JD900265, 2000.

Tan, W., Liu, C., Wang, S., Xing, C., Su, W., Zhang, C., Xia, C., Liu, H., Cai, Z., and Liu, J.: Tropospheric $\mathrm{NO}_{2}, \mathrm{SO}_{2}$, and $\mathrm{HCHO}$ over the East China Sea, using ship-based MAX-DOAS observations and comparison with OMI and OMPS satellite data, Atmos. Chem. Phys., 18, 15387-15402, https://doi.org/10.5194/acp-1815387-2018, 2018.

Thalman, R. and Volkamer, R.: Temperature dependent absorption cross-sections of $\mathrm{O}_{2}-\mathrm{O} 2$ collision pairs between 340 and $630 \mathrm{~nm}$ and at atmospherically relevant pressure, Phys. Chem. Chem. Phys., 15, 15371-15381, https://doi.org/10.1039/c3cp50968k, 2013.

Toledano, C., Cachorro, V. E., Berjon, A., de Frutos, A. M., Sorribas, M., de la Morena, B. A., and Goloub, P.: Aerosol opti- 
cal depth and Ångström exponent climatology at El Arenosillo AERONET site (Huelva, Spain), Q. J. Roy. Meteor. Soc., 133, 937-948, https://doi.org/10.1002/qj.54, 2007.

Vandaele, A. C., Hermans, C., Simon, P. C., Carleer, M., Colin, R., Fally, S., Mérienne, M. F., Jenouvrier, A., and Coquart, B.: Measurements of the $\mathrm{NO}_{2}$ absorption crosssection from $42000 \mathrm{~cm}^{-1}$ to $10000 \mathrm{~cm}^{-1}(238-1000 \mathrm{~nm})$ at $220 \mathrm{~K}$ and $294 \mathrm{~K}$, J. Quant. Spectrosc. Ra., 59, 171-184, https://doi.org/10.1016/S0022-4073(97)00168-4, 1998.

van der A, R. J., Eskes, H. J., Boersma, K. F., van Noije, T. P. C., Van Roozendael, M., De Smedt, I., Peters, D. H. M. U., and Meijer, E. W.: Trends, seasonal variability and dominant $\mathrm{NO}_{x}$ source derived from a ten year record of $\mathrm{NO}_{2}$ measured from space, J. Geophys. Res.-Atmos., 113, D04302, https://doi.org/10.1029/2007JD009021, 2008.

Volkamer, R., Spietz, P., Burrows, J., and Platt, U.: Highresolution absorption cross-section of glyoxal in the UV-vis and IR spectral ranges, J. Photochem. Photobiol. A, 172, 35-46, https://doi.org/10.1016/j.jphotochem.2004.11.011, 2005.

Volkamer, R., Baidar, S., Campos, T. L., Coburn, S., DiGangi, J. P., Dix, B., Eloranta, E. W., Koenig, T. K., Morley, B., Ortega, I., Pierce, B. R., Reeves, M., Sinreich, R., Wang, S., Zondlo, M. A., and Romashkin, P. A.: Aircraft measurements of BrO, IO, glyoxal, $\mathrm{NO}_{2}, \mathrm{H}_{2} \mathrm{O}, \mathrm{O}_{2}-\mathrm{O}_{2}$ and aerosol extinction profiles in the tropics: comparison with aircraft-/ship-based in situ and lidar measurements, Atmos. Meas. Tech., 8, 2121-2148, https://doi.org/10.5194/amt-8-2121-2015, 2015.

Vountas, M., Rozanov, V. V., and Burrows, J. P.: Ring effect: Impact of rotational Raman scattering on radiative transfer in earth's atmosphere, J. Quant. Spectrosc. Ra., 60, 943-961, https://doi.org/10.1016/S0022-4073(97)00186-6, 1998.
Vrekoussis, M., Wittrock, F., Richter, A., and Burrows, J. P.: Temporal and spatial variability of glyoxal as observed from space, Atmos. Chem. Phys., 9, 4485-4504, https://doi.org/10.5194/acp9-4485-2009, 2009.

Vrekoussis, M., Wittrock, F., Richter, A., and Burrows, J. P.: GOME-2 observations of oxygenated VOCs: what can we learn from the ratio glyoxal to formaldehyde on a global scale?, Atmos. Chem. Phys., 10, 10145-10160, https://doi.org/10.5194/acp-10-10145-2010, 2010.

Weller, R., Schrems, O., Boddenberg, A., Gäb, S., and Gautrois, M.: Meridional distribution of hydroperoxide and formaldehyde in the marine boundary layer of the Atlantic $\left(48^{\circ} \mathrm{N}-35^{\circ} \mathrm{S}\right)$ measured during the Albatross campaign, J. Geophys. Res., 105, 14401-14412, https://doi.org/10.1029/1999JD901145, 2000.

Wiedinmyer, C., Akagi, S. K., Yokelson, R. J., Emmons, L. K., AlSaadi, J. A., Orlando, J. J., and Soja, A. J.: The Fire INventory from NCAR (FINN): a high resolution global model to estimate the emissions from open burning, Geosci. Model Dev., 4, 625641, https://doi.org/10.5194/gmd-4-625-2011, 2011.

Wittrock, F., Richter, A., Oetjen, H., Burrows, J. P., Kanakidou, M., Myriokefalitakis, S., Volkamer, R., Beirle, S., Platt, U., and Wagner, T.: Simultaneous global observations of glyoxal and formaldehyde from space, Geophys. Res. Lett., 33, L16804, https://doi.org/10.1029/2006GL026310, 2006. 